NBER WORKING PAPER SERIES

\title{
HEALTH AND WEALTH ACCUMULATION: \\ EVIDENCE FROM NINETEENTH-CENTURY AMERICA
}

\author{
Chulhee Lee \\ Working Paper 10035 \\ http://www.nber.org/papers/w10035 \\ NATIONAL BUREAU OF ECONOMIC RESEARCH \\ 1050 Massachusetts Avenue \\ Cambridge, MA 02138 \\ October 2003
}

I have benefited from the helpful comments and suggestions of Dora Costa, Joseph Ferrie, Robert Fogel, Mathew Kahn, and participants in the 2003 NBER Early Indicators of Later Work Levels, Disease and Death and Cohort Studies Group Joint Meeting, the 46th National History Meeting, and seminars at Seogang and Seoul National Universities. I thank Janet Bassett and her research team for their assisting in the collection and linkage of the 1870 manuscript census, J. Kim and S. Lee for their research assistance, and Susan Jones for her editorial assistance. This study is supported by National Institute on Aging, the National Institutes of Health (P01 AG10120), and the Brain Korea 21 Project in 2003. The views expressed herein are those of the authors and not necessarily those of the National Bureau of Economic Research.

C2003 by Chulhee Lee. All rights reserved. Short sections of text, not to exceed two paragraphs, may be quoted without explicit permission provided that full credit, including $(\mathbb{C}$ notice, is given to the source. 
Health and Wealth Accumulation: Evidence from Nineteenth-Century America

Chulhee Lee

NBER Working Paper No. 10035

October 2003

JEL No. N3, I1

\section{$\underline{\text { ABSTRACT }}$}

This study explores how the health of Union Army recruits while in the service affected their wealth accumulation through 1870 . Wartime wounds and exposure to combat, measured by the company mortality from wounds, had strong negative effects on subsequent savings. Variables on illnesses while in service, if corrected for the potential bias arising from omitted variables by using instrumental variables, also greatly diminished wealth accumulations. The economic impact of poor health was particularly strong for unskilled workers. These results suggest that health was a powerful determinant of economic mobility in the nineteenth century. The strong influences on wealth accumulations of various infectious diseases, such as malaria, typhoid, and diarrhea, found in this study point out that the economic gains from the improvement of the disease environment should be enormous. This study also suggests that the direct economic costs of the Civil War were probably much greater than previously thought, if the persistent adverse effects of wartime experiences on veterans' health are considered.

Chulhee Lee

School of Economics

Seoul National University

San 56-1, Sillim-dong, Kwanak-gu

Seoul, Korea

and NBER

clee@prome.snu.ac.kr 


\section{Introduction}

There is increasing evidence of a strong association between many measures of economic status, including income and wealth, and a variety of health outcomes, such as mortality, morbidity, and self-reported health (Ettner 1996, McDonough et al. 1997, McCellan 1998, Attanasio 2000, Meara 2001). According to the head of household's 1984 self-reported general health status, for instance, those in excellent health in 1984 were $74 \%$ wealthier than respondents in fair or poor health (Smith 1999). Nutritional status (indicated by height, BMI, and caloric intake) are closely correlated with wages in many developing countries (Deolaliker 1988, Berhman and Deolaliker 1989, Strauss and Thomas 1992). Medical scientists are often convinced that variation in socioeconomic status produces health disparities, while economists tend to emphasize the influence of health on wealth.

Recent studies have attempted to measure the magnitude of wealth depletion caused by poor health and to explain the cause of lower savings among the sick. Smith (1999) reports that the mean wealth reduction caused by new severe health problems is about $7 \%$ of household wealth. This study also suggests that the major causes of wealth depletion include (1) a decline in labor supply that reduces income, (2) downward revisions in life expectancy that allow spending of precautionary savings, and (3) the reduced likelihood of leaving large inheritances.

The studies on the impact of poor health on wealth accumulation are subject to several empirical difficulties. First, since current health is in part influenced by past economic status, and since economic conditions at different ages are to an extent correlated, there is a potential endogeneity problem. Analyzing changes in wealth based on a panel dataset mitigates but does not entirely eliminate the problem. Second, in order to measure the pure health effect on wealth accumulation, it is desirable to see how unanticipated changes in health affect savings, because if people anticipate that their health will deteriorate, they will save prior to the onset of illness to take care of this contingency. For this reason, some studies use the onset of new chronic conditions as a predictor of savings, 
but while new onsets may provide the best chance of identifying health shocks, not all new onsets come as a surprise. $^{2}$

This study explores how wartime stress and health of recruits while in service affected their subsequent wealth accumulations, based on a sample of Union Army veterans linked to the 1860 and 1870 censuses as well as military records. The Union Army data have several advantages over the modern datasets commonly used for studying the impact of health on economic status, such as the Health and Retirement Survey (HRS) and the Asset and Health Dynamics of the Oldest Old Survey (AHEAD). First, we are able to mitigate the potential endogeneity problem mentioned above by looking at the behaviors of people in the past. In the mid-nineteenth century, there were few effective medical or health care services to be purchased. The most important link between economic status and health was the quality of nutrition and housing. There was less residential segregation by social class, and both the rich and the poor were exposed to a similar ecological environment. Furthermore, there was no medical insurance in the nineteenth century. Thus, we have fewer factors to mask the true saving effect of poor health in the past. ${ }^{3}$ Second, the military medical records enable us to isolate unanticipated changes in health. All recruits who

2 A number of studies have attempted to deal with this problem, employing various instruments. Ettner (1996) used the state unemployment rate, work experience, parental education, and spousal characteristics as instruments for an individuals' income. She found that the effect of income on health remains significant and even increases after instrumenting. Meer, Miller, and Rosen (2003) used the size of inheritance as an instrument for wealth. They found that the originally small but significant effect of wealth on health became statistically insignificant if instrumental variable estimation was applied.

3 The results of studies on the effects of socioeconomic status on health in the past are mixed. Steckel (1988) found that socioeconomic class differences in mortality among women and children in mid-nineteenth-century America were small based on a sample of families matched to the 1850 and 1860 censuses. Preston and Haines (1991) also reported that the influences of economic factors on child mortality at the end of the nineteenth century were relatively weak. Preston et al. (1981) suggested that the link between wealth and health became stronger over the twentieth century. In contrast, Ferrie (2003) found that socioeconomic status, especially wealth, was an important force shaping the mortality rates experienced by Americans in the middle of nineteenth century, based on a sample of the mortality schedules of the 1850 and 1860 censuses. Lee (2003) found that wealth had a significant positive effect on the health of Union Army recruits while in service. 
passed the medical examination were presumably in relatively good health at the time of enlistment. Illnesses and injuries while in service were purely unpredicted events prior to enlistment. These features of the data provide an ideal setting to analyze the influence of health on economic mobility. Finally, the Union Army data allow a rare chance to examine the association between health and economic mobility at relatively young ages. Studies based on today's data are largely concerned with individuals at middle and older ages, in part because there are relatively small variations in health among the young. But due to the extremely varied wartime experiences of the recruits, the Union Army data allow us to observe substantial disparities in health at younger ages.

This study is related to a number of important issues in the fields of labor and health economics, economic history, and medicine, such as determinants of economic mobility, economic effects of Post Traumatic Stress Disorder (PTSD), and economic costs of the Civil War. Studies on economic mobility in the nineteenth century are abundant, especially for individuals from particular ethnicities and geographical locations (Thernstrom 1973, Kearl and Pope 1986, Galenson and Pope 1989, Herscovici 1993, 1998, Conley and Galenson 1998, Ferrie 1999). As determinants of economic mobility, various human capital attributes such as age, literacy, race, length of residence, and nativity, have been employed. By considering the role of health, another important dimension of human capital, this study will broaden the understanding of this subject.

Measuring wartime stress and following upon its subsequent effects on health and mortality is an important issue in medical and epidemiological studies (Archibald and Tuddenham 1965, Beebe 1975, Berg and Richlin 1977, Dent et al. 1989, Goulston et al. 1985, Hearst, Newman, and Hulley 1986, Nefzger 1970, Lund et al. 1984, Smith et al. 1987, Spaulding 1977, Sutker el al. 1991, Ursano 1990). Since stress is not directly observable, previous studies have developed an index to proxy the severity of wartime experiences. As will be addressed below, the measures of combat exposure available from the Union Army service records are much wider in range and more detailed in characterization than those 
that have been employed in previous studies. For instance, company-level variables, such as the casualty rate of a particular company, can be constructed from the data. The richness of these data makes possible an improved measure of wartime stress. Although there is a voluminous literature on the effect of veteran status on measures of economic performance (Taussig 1974, DeTray 1982, Berger and Hirsch 1983, Schwartz 1986 Angrist 1990), little is known about how the extent of wartime stress or particular wartime events affected later economic mobility. This study will fill this gap in the literature.

Finally, this study will significantly alter our understanding of the economic costs of the Civil War. Where previous studies have mainly focused on the damages during the war itself (Goldin and Lewis 1975), my analysis of the Union Army data takes into account, in the estimation of human and physical losses, the persistent effects of military service on economic mobility of Union Army veterans after the war. In addition, where previous studies paid attention exclusively to the aggregate impact of the war, this study provides new micro-evidence on how the costs of the war were allocated across different populations and what the mechanisms of such allocations were.

\section{Data}

This article is based on a sample of the several primary data sources that were collected and linked as part of the project titled "Early Indicators of Later Work Levels, Disease, and Death" (referred to as the EI project, hereafter) jointly sponsored by the National Bureau of Economic Research, the National Institutes of Health, the Center for Population Economics at the University of Chicago, and Brigham Young University. The original population from which the sample used in this study was drawn is composed of 28,546 recruits who enlisted in the states of Connecticut, Delaware, Illinois, Iowa, Kansas, Kentucky, Maine, Maryland, Massachusetts, Michigan, Minnesota, Missouri, New Hampshire, New York, Ohio, Pennsylvania, Vermont, West Virginia, and the District of Columbia. These recruits have been linked to various data sources, such as military service 
records, pension records, and records from the 1850,1860,1900, and 1910 censuses. $^{4}$

The service records contain very detailed descriptions of the diseases or wounds that recruits suffered during military service. As soon as a recruit was too ill to report for duty, his condition was noted in morning reports. If his condition required medical attention, it was recorded in the regimental surgeon's report; if he was hospitalized, the diagnosis of the disease was described in the case history together with the ultimate outcome, such as return to service, discharge for disabilities, or death (U.S. Surgeon General's Office 1870, vol. 1). Information on disease and wounds, which was used in measuring health of recruits, was gathered from these sources. Military service records provide information on the demographic and socioeconomic characteristics of recruits prior to enlistment, including age, occupation, place of birth, and height, and military career, including rank, military duty, company, regiment, change in military status, dates of enlistment and discharge, and so on. Variables on occupation prior to military service, nativity, age, year of enlistment, and death rates of each company that were used as either measures or determinants of economic mobility or indexes of wartime stress came from these records.

For the purpose of examining the patterns of economic mobility shortly after the Civil War, 4397 recruits were located in, and linked to, the manuscript schedules of the 1870 population census. The recruits selected for the search met the following criteria: First, they were known to be alive when the 1870 census was enumerated, or information on their death dates was not available. Second, they enlisted in a state or district for which an index of the 1870 census is available, such as the District of Columbia, Delaware, Iowa, Kansas, Maine, Minnesota, Missouri, Ohio, and West Virginia. The second criterion for the sample selection is employed to reduce the costs of data collection. The information contained in pension and military records that had been already linked to the sample of recruits were

\footnotetext{
${ }^{4}$ See Fogel (1993, 2000a, 2000b, 2001) and Wimmer (2003) for more detailed explanations of the EI Project and data produced from the project. The data sets collected and linked as part of this project can be obtained from the web site of the Center for Population Economics (http://www.cpe.uchicago.edu).
} 
utilized in locating the selected recruits in manuscript census. As a result of the linkage process, 1,863 veterans ( $42.4 \%$ of those who were searched) were successfully linked to the 1870 census. Of these veterans, 1,097 men (58.8\%) were connected to the 1860 census.

Census records provide additional information on socioeconomic structure and on household structure prior to and shortly after the military service of recruits. These contain information on age, occupation, place of birth, personal and real estate wealth, place of residence, and literacy, not only for recruits themselves but also for other household members. Among the variables required for this study, wealth and place of residence at the town level prior to enlistment are found only in the 1860 census. Therefore, I limit the sample to the 1,097 recruits who were linked to both the 1860 and 1870 censuses whenever wealth or town of residence is concerned.

As can be expected from the nature of the data linkage process, the sample linked to the 1870 census is a severely selected sub-sample of the entire Union Army sample. Table 1 compares some key characteristics of recruits between the entire and selected samples. A comparison of the first and second columns of the table shows that the sample of 4,397 persons who were searched in the 1870 census is much different from the entire sample in terms of geographical and occupational compositions. In particular, recruits from the West North Central region (55\%) are heavily overrepresented in the sample searched in the 1870 census. On the other hand, recruits from the Mid Atlantic and East North Central regions account for, respectively, $9 \%$ and $20 \%$ of the sub-sample, much lower than their original shares (35\% and $42 \%$, respectively). The percentage of farmers and tenants (59\%) is also much higher for the sample searched in the 1870 census than the entire sample (49\%), primarily due to the overrepresentation of the recruits from the Mid West and the lower rate of migration of farmers. Other characteristics are generally similar between the two samples.

Additional sample selections occurred in the course of linking the sample of 4,397 men to the 1870 census. The second and third columns of Table 1 present the differences 
between the sample searched and the sub-sample linked to the 1870 census. In addition, a logistic regression was conducted to examine the correlates of probability of successful linkage to the 1870 census, using the variables included in Table 1 . The most powerful predictor of a successful linkage is whether a recruit is linked to pension records. Recruits who were linked to pension records were nearly four times as likely to be found in the 1870 census as those who were not connected to pension data. Since pension records provide useful information, especially on place of residence, that helps to locate and identify persons in manuscript schedules of censuses, it is an anticipated pattern of sample selection. Persons whose death dates are known are twice as likely to be linked to the 1870 census than those whose death dates are unknown, even after controlling for the status of linkage with pension records, the primary source of death dates. This result suggests that some recruits whose death dates are unknown may have been dead by 1870 , and, therefore, were not at risk to be found in the 1870 census. Also, recruits who were found in the 1870 census were more likely to be U.S.-born, to be farmers, to reside in either the West North Central region or the South, and to have wartime medical experiences than those not linked to the 1870 census. $^{5}$

Since the information from pension records was used in locating the veterans in the 1870 census, the sample used here is subject to additional bias problems. Recruits who got on the pension rolls early (those who were severely injured or sick while in service) could be more likely to be linked to the 1870 census, owing to the information on place of residence around 1870 . On the other hand, the majority of veterans got on the pension rolls

\footnotetext{
5 The overrepresentation of the U.S. born and greater disease cases among the recruits who were linked to the 1870 census can be explained in part by their higher linkage rate to pension records. Immigrants were less likely to be found in pension records because many foreigners who died during the early postwar years had no eligible dependents or were used behind the front and so were less likely to incur war-related disabilities (Fogel 1993). Army veterans with health problems originating from military service were more likely to apply for and receive pensions because early pension laws required such conditions. Therefore, it is not surprising that recruits who were connected to census records present more severe medical experiences while in service.
} 
after 1890 , when the eligibility condition for pensions was relaxed. ${ }^{6}$ Therefore, both the very sick, who began to receive pensions early and the very healthy, who received pensions late, could be overrepresented in the present sample. If this is the case, the effect of wartime experiences on wealth accumulation, estimated below, could be biased upward, because two extreme cases are compared. To see if veterans who got on the pension roll early and those who got late are overrepresented in the sample linked to the 1870 census, I compare the percentage distribution of the timing of the first pension application for veterans who were wounded while in service and those who were not between the full sample searched and the selected sample linked to the 1870 census. Figure 1 shows that the pattern of the difference in the timing of pension applications between injured veterans and those not wounded was similar for the full sample and the linked sample. This suggests that the potential bias problem explained above may not be too serious.

In sum, the sample used in this study is a biased sample that overrepresents the native and agricultural population in the Mid West. Therefore, the extent and patterns of wealth accumulation between 1860 and 1870 found in this study may not convey a general experience of the Union Army at large, let alone the entire northern population. However, it is not likely that the present sample will produce a serious bias in the relationship between wartime medical experiences and wealth accumulation, the main focus of this study. In spite of the potential selection bias, therefore, a careful use of the sample provides a rare opportunity to examine the effects of various health problems while in service and the extent of wartime stress on wealth accumulation in the nineteenth century.

\section{Measuring Health}

Military service during the Civil War seriously damaged the health of recruits who survived the war. As presented in Table 2, a quarter of the recruits were injured, and nearly

\footnotetext{
${ }^{6}$ For the evolution of the Union Army pension laws, see Costa (1998) and Glasson (1918).
} 
three-quarters of the veterans suffered various illnesses at least once while in service. Wartime illnesses were mainly caused by infectious diseases, although some chronic conditions such as rheumatism and hernia were also prevalent. Diarrhea was the most common disease in the army camp, contracted by $30 \%$ of the recruits in the sample, followed by malaria (19\%), respiratory infections such as pneumonia and bronchitis (7\%), measles $(6 \%)$, and typhoid (4\%). The unusually high rates of disease contraction were due to the peculiar nature of the army camp, in which a large number of men from heterogeneous socioeconomic and ecological backgrounds were confined in an extremely unhealthy environment.

Many of the recruits who contracted infectious diseases while in service, if they survived, probably recovered from the illnesses rather quickly, even before they were discharged from their service. However, the damage caused by those acute diseases may have had persistent influences on their later health. Studies have found that infectious diseases affect the odds of suffering chronic conditions such as heart, respiratory, and musculoskeletal disorders at older ages (Elo and Preston 1992, Costa 2000). I use dummy variables indicating whether a veteran experienced a particular type of wound or disease as well as wounds and illnesses in general as a measure of health.

Measurement of health based on wartime medical experiences requires an attention to omitted variables pertaining to the recruit's health status prior to enlistment. Simple models using variables on wartime traumatic events such as injury and illness as indexes of health assume that the probability of being wounded or contracting disease was unrelated to individual characteristics of the recruits. But the probability of being wounded or contracting disease was by no means equal for all recruits. It was determined in part by factors that we might consider exogenous, such as the battle experience of the company in which a recruit served. It was also determined by factors that reflect individual characteristics, some observable and some not. For example, taller and more robust men were more likely to be placed near the front lines where wounds were more likely. Men 
who were ill in hospital were not at risk for battle wounds. If individual-specific determinants of the probability of being wounded are also determinants of subsequent health, the estimated effect of the stress of being wounded will be biased.

This potential association between individual characteristics and wartime events is clearly seen in Table 3, which reports the effects of recruits' personal characteristics on their medical experiences while in service and military positions. Former farmers and rural residents, who were healthier on average prior to enlistment thanks to greater isolation from other people, were more susceptible to disease and were more likely to die from diseases they contracted than nonfarmers and urban dwellers (Table 3, columns 1 and 3). ${ }^{7}$ Native recruits were subject to a greater risk of illness than were foreigners, who had had more chances of exposure to infectious disease in the course of immigration. The different degree of immunity against pathogens is probably the most important link between the extent of exposure to disease prior to enlistment and health while in service. That is, survivors of unhealthy environments developed better immunity to some of the infectious diseases that were rampant in the army (Lee 1997, 2003).

The probabilities of being wounded and of dying from a wound while in service were not so strongly affected by individual characteristics as were the odds of contracting and dying from diseases. As noted above, however, taller recruits were significantly more likely to be killed by injury while in service. Military position, such as rank, duty, and company, was another important determinant of the extent of risk in military service. For instance, men who were assigned a non-infantry duty or who held a higher rank were less likely to die while in service than, respectively, infantrymen and privates. Assignment of military positions was, again, strongly affected by age, height, occupation, place of residence, household wealth, and nativity (Table 3, columns 5 and 6). For example, nonfarmers and natives were significantly more likely to be appointed to a higher rank, and

\footnotetext{
${ }^{7}$ Lee (2003) also found that recruits from a county with a higher child death rate were less likely to contract disease than those from a low-mortality county.
} 
to be assigned to a non-infantry duty than were, respectively, farmers and foreigners. Also, the chances of being assigned a higher rank were greater for taller or wealthier recruits than for shorter or poorer persons. This relationship is explained by a match between the quality and type of skills recruits obtained prior to enlistment and the requirements for particular military positions (Lee 1999). ${ }^{8}$

In general, stressful wartime events such as wounds and illnesses are positively correlated with superior health and productivity prior to enlistment, which, again, would be positively associated with wealth accumulation after military service. Therefore, simple models using the variables on wartime events as stress measures would induce a downward bias in estimating the effect of wartime experiences on subsequent savings. The most straightforward solution is to this problem is to employ instrumental variable regression. Specific wartime events undergone by individuals can be modeled as functions of exogenous variables which are correlated with the extent of wartime stress, but not with unobservable individual characteristics that affect economic mobility. Then the predicted probability of the event, rather than the actual events, could be used to construct indexes of wartime stress.

A company-level variable, such as the casualty rate of a particular company, is a good candidate for an instrument. Enlistees in the same company shared common experiences from training to discharge. Residents of a town were often recruited to the same company, sent to the same battle ground, and fought side by side. Consequently, all individuals in a particular company were exposed to a similar level of stress. On the other hand, the company mortality rate, especially from wounds, was only weakly correlated with individual characteristics. According to the regression results reported in Table 3, natives and nonfarmers living in rural areas tended to serve in companies with a higher injury-

\footnotetext{
${ }^{8}$ Lee (1999) suggested that higher-rank positions in the Union Army tended to be filled by individuals with better human capital attributes that would be useful for making a good officer. A military duty requiring particular skills was more likely to be given to a person possessing similar skills thanks to his occupation prior to enlistment.
} 
caused mortality compared to, respectively, foreigners and farmers. ${ }^{9}$ However, the average differences in the company mortality between natives and immigrants and between nonfarmers dwelling in rural areas and farmers were small ( $1 \%$ and $0.3 \%$ respectively).

The first row of Table 4 presents several characteristics of recruits who served in companies with particular rates of death from wounds. It suggests that the degree of wartime stress undergone by recruits greatly varied across different companies. Twenty-two percent of the recruits in the sample served in companies in which not a single person was killed in action. In contrast, nearly $11 \%$ of the recruits fought in a company in which more than $10 \%$ of enlisted men died from wounds. Some recruits in the former category belonged to militia units formed exclusively from men of their locality and never saw battle. Many of them were recruited (and released) before the major battles or after Lee's surrender, as indicated by the short average length of service (1.2 years), and thus escaped not only the stress of combat but even a substantial threat of exposure to combat (Hamersly 1888). These $22 \%$ of recruits are clearly distinct from others in terms of the proportion of recruits who suffered from illnesses while in service ( $46 \%$ compared to $72 \%$ for the entire sample) and the average rate of company mortality from illness $(5.3 \%$ in contrast to $10 \%$ for the entire sample). ${ }^{10}$ Although the wartime experiences of those $22 \%$ of recruits were apparently more favorable than those of the rest of the recruits, the relationship between the company mortality rate from wound and other company casualty rates, such as mortality from illness and discharge because of wounds or illness, does not appear to be linear. This

\footnotetext{
${ }^{9}$ It is unclear why native farmers were more likely to be enlisted in higher-risk companies than nonfarm immigrants. A possible explanation is that they were (or were viewed as) more loyal to the Union in comparison with nonnatives from cities (Lee 1999). Many foreigners in the North were lukewarm or hostile to the entire war effort, especially those who perceived it as an unnecessary crusade to free slaves (Murdock 1964, Vinovskis 1990). Those who participated in draft resistance or evasion during the Civil War were often characterized as lower-class immigrants, living in cities and allied with Democratic politicians (Lavine 1981). A commanding officer, when sending a unit to a dangerous mission, would have chosen a company composed of more reliable recruits to reduce the risk of desertion.

${ }^{10}$ In this sense, recruits who served in companies with no deaths from injury may be used as a control group where the effect of participation in the Civil War on economic mobility is examined.
} 
suggests that recruits who were exposed to bloody combat, regardless of how often, were subject to a higher level of stress than those who did not experience any serious battle.

Other candidates for valid instruments are the year and month of enlistment. The severity of wartime experiences of recruits heavily depended upon the year of enlistment. As presented in Table 4, the earlier a person entered the army the greater the probabilities of getting wounded and of suffering from illnesses. This is mainly due to the fact that earlier enlistees served longer on average as the war lasted long enough for them to finish their three-year term. In addition, the difficulties of military missions and the disease environment changed year to year.

The chances of contracting diseases and being wounded while in service also differed remarkably by the month of enlistment. The wartime casualty rate was particularly severe among recruits who enlisted in summer. In contrast, recruits who joined the army in spring or winter fared relatively well. Again, the difference in the average length of service is a major explanation for the seasonal disparity in the casualty rates. Summer enlistees served the longest term (two and a half years), while those who enlisted in spring served the shortest (less than ten months). This is because most recruits who enrolled in the Union Army in 1861 enlisted shortly after Lincoln's call for 42,000 three-year army volunteers on May 3, and Congress' authorization of another one million three-year volunteers in June (McPherson 1988, chapter 10). Another explanation, especially for the high rate of illness among those who enlisted in June through August, is the particularly strong influences of infectious diseases in summer. It is documented in the medical histories of the Civil War that the earlier seasoning period in the army was most critical for the survival of recruits. During this period enlistees with limited prior development of immunity were exposed to a pool of infectious diseases in the army (Steiner 1968). Therefore, it would be more dangerous to be first confined to the unhealthy army environment in summer when various infectious diseases were rampant.

Visible medical experiences are not the only indicators of the extent of health 
damages suffered by veterans who fought in a bloody war. It has been reported that PostTraumatic Stress Disorder (PTSD) was widespread and severe among the veterans who served in Vietnam and the Civil War (Dean, Jr. 1997). Since stress is not directly observable, it is necessary to develop an index to proxy the severity of wartime experiences. Most previous studies have used a single wartime event as an index, such as being wounded in combat, fired upon in combat, stationed in a combat zone, and being captured by enemy. Epidemiologists studying PTSD in contemporary veterans reported that suffering these events had persistent and statistically significant effects on the later mortality and morbidity of veterans who fought in World War II, the Korean War, and the Vietnam War (Archibald and Tuddenham 1965, Beebe 1975, Berg and Richlin 1977a-d, Dent et al. 1989, Goulston et al. 1985, Hearst, Newman, and Hulley 1986, Nefzger 1970, Smith et al. 1987, Spaulding 1977, Sutker el al. 1991, Ursano 1990). Based on a sample of Union Army veterans, Costa (1993) found that imprisonment by the enemy, being wounded, and being discharged for injury or illness significantly increased the risk that veterans who survived to 1890 would die between the ages of 55 and 77.

Based on the above results, I use below the following indexes as measures of wartime stress and insults to health caused by war. First, the company mortality from wounds is employed as an index of wartime stress. Considering the particularly favorable wartime experiences of the recruits who served in companies with no deaths from injury, and the nonlinear relationship between the injury-caused mortality and other measures of casualties, I use a set of four dummy variables representing particular rates of death from injury: (1) zero (2) $3 \%$ or less (3) $3 \%$ to $5 \%$, and (4) more than $5 \%$ (denoted as "Co wound mortality 1-4"). Second, I use simple dummy variables on wartime medical events. The wartime events considered here include wounds in general, five types of wound by location, illnesses in general, and 10 particular diseases that were common among Union Army recruits, including typhoid, smallpox, measles, diarrhea, respiratory infections, malaria, tuberculosis, rheumatism, syphilis, and hernia. Finally, to address the issue of the omitted 
variable problem, I estimate the probabilities of particular wartime events predicted by several instrumental variables, including polynomials of the company mortality from wounds, dummy variables for the year and month of enlistment, and some combination of the three instruments. The predicted probability of each event is used as an index of insults to health while in service, corrected for the potential bias arising from omitted variables.

In addition to the variables on wartime experiences I add variables on height at the time of enlistment as an indicator of the nutritional status of recruits. Since it is inappropriate to compare the height of a recruit at a growing age with those who had already gained their final stature, it is desirable to use an age-standardized measure of height. Accordingly, I construct five dummy variables on height (Height 1 to Height 5), each of which represents a quintile of the height distribution for a particular age. For age 18, for example, recruits with heights from 64.5 inches to 67 inches were classified as the fourth quintile; for age 19, recruits whose heights were 65 inches to 66.25 inches were included in the same category. The height distribution by age was obtained from the entire Union Army sample of about 35,000. To all recruits 23 and older, a single height distribution was applied, assuming that height after age 23 remained unchanged.

\section{Wartime Stress, Health, and Wealth Accumulation}

The magnitude of wealth accumulation is a widely used measure of economic mobility in the nineteenth century, along with occupational movement. Since wealth acquisition captures changes in economic status within each category of occupations, it provides an even more comprehensive yardstick of economic mobility. The literature on wealth accumulation in the nineteenth century is voluminous. It has been established by these studies that the age profile of wealth was inverse- $U$ shaped, that duration of residence in America or in a particular locality was positively related with the magnitude of wealth, and that the size and pattern of wealth accumulation differed by ethnicity (Soltow 1975, Kearl and Pope 1986, Pope 1989, Galenson and Pope 1989, Galenson 1991, Ferrie 1999). 
To my knowledge, however, the effect of health, a potentially important element of wealth mobility, has not been explored yet.

The accumulation of physical wealth of a person between two points in time can be modeled as determined by (1) the initial stock of human capital (such as health, ability, skills, and so on), (2) individual choice (such as occupational shift, geographical movement, and family formation), (3) change in the value of wealth, and (4) luck (Kearl and Pope 1986). The adverse influences of wartime events are expected to have affected the size of wealth accumulation of the Union Army veterans via two different paths, by directly impairing their health, and by altering individual choices. Though not taken up in this paper, I have examined how the combat exposure, wounds, and illnesses recruits experienced while in service affected their subsequent economic choices through 1870 using the same data. I found that that greater combat exposure, measured by the company mortality from wounds, strongly reduced occupational mobility. ${ }^{11}$ The adverse effects of wartime stress and medical events on geographical movement and family formation by 1870 do not appear to be strong. The empirical analyses given in this section estimate the direct effects of wartime events while in service on wealth accumulation between 1860 and 1870, after controlling for occupational changes, geographical migration, and number of children, as well as other personal characteristics. The results given below do not change much if the variables on choice are excluded, which implies that the effect of health on wealth accumulation is largely direct.

Table 5 presents the results of baseline regressions that examine the effects of combat exposure measured by the company mortality from wounds, wounds, and illnesses on wealth accumulation between 1860 and 1870. Exploiting the fact that both the 1860 and

\footnotetext{
${ }^{11}$ I used three different measures of occupational mobility. First, I used the probability of not being gainfully employed in 1870 to see if poor health prohibited veterans from labor force participation. Second, I employed the probability that persons employed in unskilled occupations at the time of enlistment moved up to farming, skilled, or white-collar occupations by 1870 . Finally, I used the rate of change in the estimated occupational income scores.
} 
1870 censuses report personal and real estate wealth separately, three different measures of wealth, namely, logarithms of total, personal, and real wealth, are used in the analysis. ${ }^{12}$ In addition to the variables representing the health of recruits while in service, the following control variables are included. First, to control for the initial wealth, the logarithms of the 1860 total, personal, and real wealth are included. In addition, the logarithm of the 1860 wealth held by other family members is added to consider the additions of wealth from inheritance or gift. As indexes pertaining to the initial stock of human capital, I employ variables on 1860 age, place of birth, ability to read and write, and height. I also include variables on the region of residence at the time of enlistment and the size of town of residence as of 1860 and 1870 to control for the potential variations in the conditions of labor and property markets.

As controls for the choice of veterans, the following variables are included. First, the number of children younger than age 10 and those 10 and older for 1860 and 1870 is included to consider the effects of family size and structure. Presence of older children would have a positive effect on wealth accumulation by providing additional family labor. On the other hand, a large number of younger children could impede wealth accumulation owing to more expenditures on children. ${ }^{13}$ In addition, dummy variables on geographical mobility (same county, moved to a different county within the same state, and moved to a different state) are added to capture the effect of migration on wealth. The effect of geographical migration on wealth accumulation is ambiguous, even though it is more likely that its net effect is negative at least in the short-term given the large cost associated with

12 For recruits who possessed no wealth, the log of wealth was given as zero.

${ }^{13}$ It should be noted that in the analysis of wealth accumulation, variables on occupational shift, geographical movement, and the number of children are subject to a potential endogeneity problem. That is, for example, a wealthier person would be able to support more children, and spare a fund for relocation. I do not attempt to address this issue here, because it is difficult to find an instrumental variable to cure this problem, and the main concern of this study is to examine the effects of wartime events on wealth accumulation. 
relocation. Finally, dummy variables for occupational changes are included to account for the effect of occupational change on wealth accumulation. ${ }^{14}$ Since a better occupation pays more on average, it is expected that the extent of occupational mobility is positively associated with wealth. If the cost of training required for a job switch is too large, however, it is possible that occupational change diminished the size of wealth accumulation, at least in the short-term.

The results suggest that combat exposure and wounds while in service had strong negative effects on the total 1870 wealth, controlling for the total 1860 wealth and other personal characteristics. On the other hand, illnesses in general had no significant effect on wealth accumulation. The effects of wartime events are generally stronger for personal wealth than for real wealth. For personal wealth, the effect of the company mortality from wounds largely reflects the difference between the veterans who served in a company with no single person killed in action and the rest who served in a company sent on more dangerous missions. For real wealth, only those who served in the category of highestmortality companies had statistically significant disadvantages. The significant effect of wounds on wealth is found only for personal wealth; its effect on real wealth is negative,

14 The identification of farmers at the time of enlistment is subject to errors; therefore, the extent of occupational mobility suggested here could be biased to some extent. For recruits who were linked to the 1860 census, the direction of bias is unclear. It is assumed in the above method that persons who had real estate wealth in 1860 continued to possess wealth at the time of enlistment, which may not be true. This tends to overstate the proportion of farmers, and understate the degree of occupational mobility, because some cases of switching from tenant farmer to farmer will be counted as no change in occupation. On the other hand, persons who owned no real estate wealth are assumed to remain landless by the time of enlistment. Since some of these persons moved up to self-employed farmers, this assumption will lead to an underestimation of the proportion of farmers at the time of enlistment, and to an overstatement of the extent of occupational mobility. It is unknown which type of bias is greater. For recruits who were not linked to the 1860 census, it is likely that the extent of occupational mobility suggested here is subject to a downward bias. It is implicitly assumed that farmers who possessed real wealth at the time of enlistment continued to do so by 1870 , and those without farm when entering the army also continued to do so by 1870 . Given that the direction of occupational mobility is upward on average, the above assumption will overstate the share of self-employed farmers at the time of enlistment, and thus understate the extent of mobility from tenant farmers to self-employed farmers. 
too, but statistically insignificant. ${ }^{15}$

The effect of the 1860 other family wealth is small and statistically insignificant for all three specifications, indicating that the influence of inheritance or gift was probably unimportant. The coefficients on age and age squared show an inverse-U shaped age-wealth profile, as is found in other studies on wealth accumulation. ${ }^{16}$ The total wealth of natives was not significantly different from that of immigrants, controlling for other personal characteristics. Illiteracy greatly hampered wealth accumulation, especially personal wealth. The result for height weakly supports the findings of previous studies suggesting that superior nutritional status is associated with greater productivity (Deolaiker 1988, Berhman and Deolaiker 1989, Strauss and Thomas 1992). That is, taller persons, who belonged to the top quintile, had significant advantages in total wealth accumulation. As for the regional differences, veterans who lived in the North West Central and New England at the time of enlistment acquired significantly more real wealth than did others. The result for the size of location suggests that the magnitude of wealth accumulation, real wealth in particular, was significantly smaller for those who resided in urban areas in 1870 than the rest of the veterans.

The number of children younger than age 10 in 1860 had a negative effect on both types of wealth as of 1870 , although it misses statistical significance by a small margin. It probably reflects the influence of the cost required for raising children. In contrast, the number of children younger than age 10 in 1870 had a strong positive effect on both types of wealth. This relationship could be explained in terms of a wealth effect in choosing the number of children. The presence of children age 10 and older had a positive effect on wealth accumulation, but it is statistically significant only for personal wealth.

\footnotetext{
15 The particularly strong effect of health on personal wealth is largely due to the occupational difference that will be discussed below. The impacts of wounds and exposure to combat on wealth were especially powerful for unskilled workers for whom personal wealth was the major form of savings.

${ }^{16}$ Wealth peaked at age 31 for total wealth, 30 for personal wealth, and 33 for real wealth.
} 
Geographical mobility was associated with a decrease in wealth accumulation. Longdistance migration, indicated by moving across a state border, had a much greater negative effect on wealth than a shorter move to a different county within the same state, especially for real estate wealth.

The results for dummy variables for occupational change between 1860 and 1870 suggest that veterans who were farmers either in 1860 or 1870 were wealthier in 1870 than those who never became farmers. Secondly, veterans who were skilled workers in both 1860 and 1870 were wealthier than those who were unskilled workers either in 1860 and 1870. I also used another measure of occupational mobility, namely, the rate of change in the estimated occupational income scores. ${ }^{17}$ The result of the alternative regression, not reported here, shows a strong positive effect of occupational mobility on the 1870 wealth. If the variable on occupational mobility is omitted from the regression, the size of the coefficients on the company mortality slightly increases. ${ }^{18}$ It suggests that the degree of combat exposure had a negative indirect effect on wealth accumulation through occupational mobility, but such an effect is relatively small. On the other hand, the coefficient for wounds diminishes a bit if variables on occupational change are omitted. It implies that occupational switch helped wounded veterans overcome their disadvantages to some extent.

17 This score was estimated by Ferrie (1999) based on a regression with the natural log of real estate wealth as the dependent variable and age, age squared, and age cubed, controls for region of residence and size of location, along with dummy variables for 157 occupation titles, as regressors. The coefficients on the occupational dummies, evaluated at age 30 , were taken to represent differences in income within three broad occupational classes: white collar, skilled, and unskilled. These dummies were adjusted, taking into account the skill premia found by Goldin and Margo (1992). See Ferrie (1999, Appendix D) for the detailed method of imputation and data on imputed income scores. The occupation at enlistment as of 1870 was coded into the three-digit occupation codes for the 1950 census (Bureau of Census 1950, Ruggles and Sobek 1998), and matched to the occupational income socres.

18 The percentage change in the three dummy variables on the company mortality was $45 \%$ for the lower-mortality companies (Co wound mortality 2 ) and $17 \%$ for the next category (Co wound mortality). The coefficient for highest-mortality companies (Co wound mortality 4) remained unchanged. 
Table 6 reports the results of regressions in which more detailed classifications of wounds and illnesses are employed. Regression coefficients for all other control variables are excluded from the table to save the space. The results for these variables are similar to the results reported in Table 5. Among wounds on various body parts, injuries to a leg or foot had the most powerful negative effect on wealth accumulation. As in the case of illnesses in general, specific diseases had no significant effects on wealth accumulation. The only exception is diarrhea, which exerted a strong negative effect on total and personal wealth accumulations.

To address the potential omitted variable problem that might produce an downward bias in the effect of wartime medical events, especially diseases, on wealth accumulation, I conducted instrumental variable estimations. As noted above, I use three instrumental variables that are correlated with the probabilities of being injured and suffering from illnesses while in service, but not related to the health of recruits prior to enlistment, namely, the polynomials of the company mortality from wounds, year of enlistment, and month of enlistment. I also use combinations of the three instruments. The predicted probabilities of wartime events are highly correlated with each other. This is not too surprising because these variables are all estimated based on the same set of instrumental variables. Since the results of regression analyses that include these variables together as independent variables exhibit symptoms of multicollinearity, I examine the effect of each wartime event one at a time. Table 7 reports the regression coefficients for the variables for wartime events, estimated from 85 regressions. The results for other variables, omitted from the table, are generally similar to those reported in Table 5 .

The results show that illnesses while in service had strong negative effects on wealth accumulations if instrumental estimations are used. Although the magnitudes of coefficients and the degree of significance vary depending on the choice of instrumental variable, all four sets of instruments provide considerably consistent results. The coefficients on illnesses in general are all statistically significant, with their magnitudes 
ranging from -1.24 to -1.55 . The results for specific diseases are less robust, but still exhibit a considerable regularity in terms of statistical significance and relative size, especially for more common diseases such as diarrhea (contracted by 30\%), malaria (19\%), and rheumatism (10\%). For instance, the coefficients for diarrhea are all significant for the four specifications, with their sizes ranging from -1.62 to -2.20 . Similarly, the coefficients for malaria are all significant, with their magnitudes ranging from -1.71 to -3.32 . Other specific diseases whose impacts on wealth accumulation were significant for two or more specifications include typhoid, measles, respiratory infections, tuberculosis, and syphilis.

According to the results, the magnitude of the loss of wealth caused by exposure to combat, wounds, and illnesses while in service is large. Applying the estimated regression coefficients reported in Table 5, I obtain a rough estimate of the decrease in wealth accumulation caused by each wartime event, evaluated at the mean total 1870 wealth (\$2052). First, men who served in a company that lost more than $5 \%$ of its men due to injury would accumulate $\$ 1109$, only $54 \%$ of the amount acquired by men enlisted in a company with zero mortality from wounds. ${ }^{19}$ If the coefficient for the simple dummy variable is taken, veterans who were injured while in service would have acquired $\$ 1418$, only two-thirds of the mean wealth for the entire sample used in the analysis.

Table 8 presents a summary of the results of regressions conducted separately for three occupational categories, namely, farmers, white-collar and skilled workers, and unskilled workers. ${ }^{20}$ The results suggest that the impact of poor health on wealth accumulation was quite different for men employed in different occupations. The wealth losses caused by wartime medical and military experiences were more severe for veterans

19 The $\log$ of the mean total wealth as of 1870 was 7.6266. Assuming persons in the control group (men who served in companies with no persons killed by injury) possessed the same amount of total wealth, the mean total wealth of veterans who served in a company with the mortality from wounds greater than $5 \%$ is calculated as $7.6266-0.6151=7.0115$, which is $\$ 1109$.

${ }_{20}$ It would be useful to divide the non-farm occupations into white-collar and blue-collar occupations. There are too few white-collar workers in the sample (less than 70) to conduct the regression analysis separately for white-collar workers. 
who were unskilled workers at the time of enlistment. The magnitudes of the negative effects of wounds and the company mortality from wounds are much larger than the effects found from the entire sample. In contrast, the wealth accumulations of white-collar and skilled workers between 1860 and 1870 were not affected significantly by wounds or combat exposure while in service. For farmers, wartime wounds had a relatively small effect on wealth accumulations. If instrumental estimation is employed, wartime illnesses greatly reduced wealth accumulations of white-collar and skilled workers, and manual laborers. But farmers were not damaged much by illnesses. The particularly strong impacts of wartime events found for the unskilled, for whom personal wealth was the major form of savings, explains why health affected personal wealth more significantly in the results for the entire sample (Table 5). The type of wounds or illnesses that affected wealth accumulation also differed by occupation. For unskilled workers, the effect of leg and foot injuries was particularly strong. For white-collar and skilled workers, on the other hand, wounds to an arm or hand had a strong impact on wealth accumulation, although it misses statistical significance by a small margin. For farmers, unclassified wounds caused the largest damage.

A possible explanation for the occupational differences in the impact of health on wealth accumulations is the difference in the type of human capital required for each job. It is likely that wartime wounds and combat exposure damaged the physical attributes of veterans' human capital such as functional abilities and physical strength rather than their skills or knowledge. Therefore, the economic impacts of wartime medical experiences should be greater for persons employed in manual jobs than those engaged in occupations that require non-physical human capital.

Another hypothesis is that farmers, white-collar workers, and the skilled had advantages over unskilled workers in coping with physical damages because they were more likely to be self-employed and to initially possess wealth. Thanks to the greater job flexibility allowed by self-employment, it would be easier for them to adjust the type and 
intensity of work according to their health conditions. ${ }^{21}$ Farmers, for example, would be able to adjust the amount of work by modifying acreage or crop mix. Also, they could utilize the service of family members or hire farm laborers. It is not likely that unskilled laborers had such options.

\section{Conclusions and Further Implications}

This study has explored how the wartime stress and health of Union Army recruits while in service affected their wealth accumulation through 1870 , based on a sample of men successfully linked to military records and the manuscript schedules of the 1860 and 1870 censuses. This study, relying on the data from the past, has several advantages over other studies on the relationship between health and economic performances based on modern data. First, we are able to mitigate the potential endogeneity problem arising from the fact that current health is in part influenced by past economic status because economic conditions at different ages are to an extent correlated. It is also because health was less influenced by economic status in the past than today because there were less medical interventions to purchase, and because the wartime experiences enable us to isolate unanticipated changes in health. Secondly, the data used in this study allow a rare chance to examine the association between health and economic mobility at relatively young ages.

I use the following indexes as measures of wartime stress and insults to health caused by war. First, I use the company mortality from injury, which reflects experiences shared by enlistees in the same company from training to discharge. Second, I use dummy variables on wartime medical events such as wounds and illnesses in general, five types of wounds by location, and ten particular diseases that were common among

\footnotetext{
${ }^{21}$ Older farmers in the past postponed the timing of retirement by adjusting the amount and intensity of their work in accordance with changes in their health and economic needs (Pedersen 1950). This flexibility of farming was one reason why the labor force participation rate of older males in the late nineteenth and early twentieth centuries was higher for farmers than for nonfarmers (Lee 2002).
} 
Union Army recruits, including typhoid, smallpox, measles, diarrhea, respiratory infections, malaria, tuberculosis, rheumatism, syphilis, and hernia. One difficulty of using these wartime events as determinants of economic mobility is that the odds of suffering these events were influenced by personal characteristics of recruits pertaining to their health. In particular, recruits from healthier environments were more likely to contract diseases, and taller persons were at a higher risk of being wounded. Therefore, the variables on wartime events are subject to a bias arising from omitted variables pertaining to the health of recruits that are correlated with both the probability of undergoing wartime medical events and economic mobility. I address this problem using several instrumental variables, such as the company mortality from wounds, year of enlistment, and month of enlistment, which are uncorrelated with the health prior to enlistment but correlated with the risk of suffering wounds or illnesses while in service. Consequently, the probability of each wartime event predicted by instrumental variables was used as the third index of insults to health while in service.

Veterans who served in a company that underwent more dangerous military missions acquired much less wealth, especially personal wealth, than those enlisted into a company with a lower casualty rate. For instance, men who fought in a company that lost at least $5 \%$ of its men due to injury would accumulate only $54 \%$ of the amount acquired by men who entered a company with zero mortality from wounds. Wounds while in service also had a strong negative effect on wealth accumulation. In contrast, simple dummy variables for illnesses in general as well as ten particular diseases had no significant effects on wealth accumulation. If instrumental variable estimation is employed, however, illnesses while in service turned out to have greatly diminished wealth accumulation. Many particular diseases, especially diarrhea, malaria, rheumatism, and tuberculosis, also had strong negative impacts on wealth accumulation. The influences of wartime medical and military experiences were particularly strong for unskilled workers compared to farmers and skilled workers. 
The results of this study suggest that health was a powerful determinant of economic mobility in the nineteenth century. It is particularly revealing that infectious diseases such as diarrhea, malaria, and tuberculosis exerted strong influences on wealth accumulation. It is well documented that infectious diseases affect the probability of suffering chronic conditions such as heart, respiratory, and musculoskeletal disorder at middle or older ages (Elo and Preston 1992, Costa 2000). The present study adds to this literature that the adverse influences of infectious diseases could come out at relatively young ages in the form of reduced productivity.

Also the results provided here suggest that the decline in the prevalence rate of various infectious diseases would have brought a large saving of economic costs arising from poor health. According to the estimate reported in Table 7, for instance, a 10\% increase in the probability of contracting malaria was associated with a $22 \%$ decline in total wealth on average, if evaluated at the mean wealth. Even if the lowest estimate is applied, the economic benefits of reducing the prevalence rate of malaria should have still been substantial, $13 \%$ of the average wealth. If the effect of the decline in all infectious diseases is combined, the economic gains from the improvement of the disease environment would have been enormous.

This paper also suggests that the direct economic costs of the Civil War were much greater than has previously been thought. Goldin and Lewis (1975) estimated that the dollar amount of human losses arising from deaths and wounds was $\$ 1.3$ billion for Union soldiers and $\$ 945$ million for Confederate troops, accounting for $37 \%$ and $28 \%$ of the total direct costs of the Civil War for the North and the South, respectively. ${ }^{22}$ It should be noted that more than two-thirds of recruits succumbed to disease while in the service, while about $20 \%$ of soldiers were wounded. If this estimate is correct, therefore, it understates the entire

\footnotetext{
22 These costs include $\$ 955$ million for 360,000 Union soldiers killed, $\$ 365$ million for 275,175 Union soldiers wounded, \$684 million for 258,000 Confederate troops killed, and \$261 million for 197,000 Confederate troops wounded.
} 
direct costs because the economic losses due to degraded health of the recruits who survived the war without being wounded are not considered.

A rough estimate of the wealth losses of Union Army veterans who survived the war can be given as follows. Suppose that the recruits who served in a company in which no one was killed by injury while in service were similar to those who did not join the army in terms of the size of wealth accumulation. The underlying assumption is that these $20 \%$ of recruits were not damaged by military service at all. The regression coefficient on the dummy variable of the company mortality from wounds $(-0.55)$ suggests that individuals who served in the army during the war accumulated $\$ 868$ less by 1870 than those who did not join the army. The present value of wealth losses caused by participating in the war as of 1861 in 1861 dollars is about $\$ 408$, if the discount rate is assumed to be $6 \%{ }^{23}$ If this estimate is regarded as a per capita loss for about 1.8 million Union Army recruits who survived the war, the total economic losses caused by wartime damages to health for the North is $\$ 734$ million, more than twice as large as the $\$ 365$ million, cost of wartime wounds estimated by Goldin and Lewis (1975). This amount is probably a lower bound estimate of the economic costs of health problems caused by the war for the following reasons. First, it only considers the wealth losses through 1870. If the adverse economic impacts of wartime experiences lasted longer, their lifetime costs would have been even larger. Second, the economic performances of veterans who served in a company with no deaths from wounds were presumably not as good as those who did not serve in the army, as assumed above, because they also were exposed to diseases and wartime stress to some extent.

\footnotetext{
23 The choice of the discount rate of $6 \%$ comes from Goldin and Lewis (1975). The consumer price index used for converting 1870 dollars into 1861 dollars is 27 for 1861 and 38 for 1870 (U.S. Bureau of the Census 1975, E135). The present value of the losses evaluated in 1861 was calculated by discounting the estimated value by $1 /(1.06){ }^{9}$
} 


\section{References}

Angrist, J. 1990. "Lifetime Earnings and the Vietnam Era Draft Lottery: Evidence from Social Security Administrative Records, American Economic Review 80, 313-336.

Archibald H. C., and Tuddenham, R. D. 1965. "Persistent Stress: Reaction after Combat," Archives of General Psychiatry 12, 475-81.

Attanasio, O. P., and H. W. Hoynes. 2000. "Differential Mortality and Wealth Accumulation," Journal of Human Resources 35, 1-29.

Beebe, Gilbert W. 1975. "Follow-up Studies of World War II and Korean War Prisoners, II: Morbidity, Disability, and Maladjustments," American Journal of Epidemiology 101, 400422.

Behrman J.R., and A.B. Deolaliker. 1989. "Agricultural Wages in India: The Role of Health, Nutrition, and Seasonality," In D. Sahn, ed., Seasonal Variability in Third World Agriculture. Baltimore: Johns Hopkins University Press, 107-17.

Berg, S. William and Milton Richlin. 1977a. "Injuries and Illnesses of Vietnam War POWs, I. Navy POWs,” Military Medicine 143, Jul., 514-517.

Berg, S. William and Milton Richlin. 1977b. "Injuries and Illnesses of Vietnam War POWs, II. Army POWs,” Military Medicine 143, Aug., 598-602.

Berg, S. William and Milton Richlin. 1977c. "Injuries and Illnesses of Vietnam War POWs, III. Marine Corps POWs,” Military Medicine 143, Sept., 678-679.

Berg, S. William and Milton Richlin. 1977d. "Injuries and Illnesses of Vietnam War POWs, IV. Comparison of Captivity Effects in North and South Vietnam," Military Medicine 143, Oct., 757-761.

Berger, M., and B. T. Hirsch. 1983. "The Civilian Earnings Experience of Vietnam Era 
Veterans," Journal of Human Resources 18, 455-479.

Bodnar, J. 1985. The Transplanted: A History of Immigrants in Urban America, Bloomington: Indiana University Press.

Conley, T. G., and D. W. Galenson. 1998. "Nativity and Wealth in Mid-Nineteenth-Century Cities," Journal of Economic History 58, 468-493.

Costa D. L. 1993. "Health, Weight, Wartime Stress, and Older Age Mortality: Evidence from Union Army Records," Explorations in Economic History 30, 424-49.

. 1998. Evolution of Retirement, Chicago: University of Chicago Press.

. 2000. "Understanding the Twentieth-Century Decline in Chronic Conditions among Older Men," Demography 37, 53-72.

Dent, Owen F., B. Richardson, S. Wilson, K. Goulston and C. Murdoch. 1989. "Postwar Mortality among Australian World War II Prisoners of the Japanese," Medical Journal of Australia 150, 378-382.

Dean, E. C. Jr., Shook over Hell: Post-Traumatic Stress, Vietnam, and the Civil War, Cambridge: Harvard University Press.

Deolaliker, A. B. 1988. "Do Health and Nutrition Influence Labor Productivity in Agriculture? Econometric Estimates for Rural India," Review of Economics and Statistics $70,406-413$.

DeTray, D. N. 1982. "Veteran Status as a Screening Device," American Economic Review 72, 133-142.

Elo, I. T., and S. H. Preston. 1992. Effects of Early-Life Conditions on Adult Mortality: A Review," Population Index 58, 186-212. 
Ettner, S. 1996. "New Evidence on the Relationship between Income and Health," Journal of Health Economics 15, 67-85.

Ferrie, J. P. 1999. Yankeys Now, New York: Oxford University Press.

Figley C. R. 1977. "Symptoms of Delayed Combat Stress among a College Sample of Vietnam Veterans," Military Medicine 143, 107-10.

Fogel R. W. 1993. "New Sources and New Techniques for the Study of Secular Trends in Nutritional Status, Health, and Mortality, and the Process of Aging," Historical Methods 26, $5-44$.

.2000a. Public Use Tape on the Aging of the Veterans of the Union Army Data User's Manual: Military, Pension, and Medical Records 1820-1940, Version M-5, Center for Population Economics, University of Chicago and Department of Economics, Brigham Young University.

2000b. Public Use Tape on the Aging of the Veterans of the Union Army Data User's Manual: U.S. Federal Census Records 1850, 1860, 1900, 1910, Version C-3, Center for Population Economics, University of Chicago and Department of Economics, Brigham Young University.

. 2001. Public Use Tape on the Aging of the Veterans of the Union Army Data User's Manual: Surgeon's Certificates 1862-1940, Version S-1 Standardized, Center for Population Economics, University of Chicago and Department of Economics, Brigham Young University.

Foy D. W., D. B. Rueger, R. C. Sipprelle, and E. H. Carroll. 1984, "Etiology of Post Traumatic Stress Disorder in Vietnam Veterans: Analysis of Premilitary, Military, and Constant Exposure Influences. Journal of Consulting and Clinical Psychology 52, 79-87.

Frye, J. S., and R. A. Stockton. 1982, "Discriminant Analysis of Post Traumatic Stress Disorder among a Group of Vietnam Veterans. American Journal of Psychiatry 139: 52-56. 
Galenson, D. W. 1991, "Economic Opportunity on the Urban Frontier: Nativity, Work, and Wealth in Early Chicago, Journal of Economic History 51, 581-603.

Galenson, D. W., and C. Pope. 1989. "Economic and Geographic Mobility on the Farming Frontier: Evidence from Appanoose County, Iowa, 1850-1870," Journal of Economic History 49, 635-55.

Glasson, W. H. 1918. Federal Military Pensions in the United States. New York: Oxford University Press.

Geary, J. W. 1991. We Need Men: The Union Draft in the Civil War. Dekalb: Northern Illinois University Press.

Goldin, C. D., and F. D. Lewis. 1975. "The Economic Cost of the American Civil War: Estimates and Implication,”. Journal of Economic History 35, 299-326.

Goldin, C. D., and R. Margo. 1992. "Wages, Prices, and Labor Markets Before the Civil War," In C. Goldin and H Rockoff, eds., Strategic Factors in Nineteenth Century American Economic History. Chicago: University of Chicago Press.

Goulston, Kerry J. et al. 1985. "Gastrointestinal Morbidity among World War II Prisoners of War: 40 Years On," Medical Journal of Australia 143, 6-10.

Hamersly, T. H. S. 1888. Complete Army and Navy Register of the United States of America, from 1776 to 1887 . New York: THS Hammersly, pub.

Hearst, N, T. B. Newman, and S. B. Hulley. 1986. "Delayed Effects of the Military Draft on Mortality: A Randomized Natural Experiment," New England Journal of Medicine 314, 620-624.

Herscovici, S. 1993. "The Distribution of Wealth in Nineteenth-Century Boston: Inequality among Natives and Immigrants, 1860. Explorations in Economic History 30, 321-55. 
. 1998. "Migration and Economic Mobility: Wealth Accumulation and Occupational Change among Antebellum Migrants and Persisters, Journal of Economic History 58, 927-956.

Kearl, J. R., and C. Pope. 1986. "Choices, Rents, and Luck: Economic Mobility of Nineteenth-Century Utah Households, In S. Engerman, and R. Gallman, eds., Long-term factors in American economic growth. Chicago: Chicago Univ. Press, 215-260.

Kemp, T. R. 1990. "Community and War: The Civil War Experience of Two New Hampshire Towns. In Vinovskis, M. A. ed., Toward A Social History of the American Civil War. New York: Cambridge Univ. Press, 31-77.

Lavine, P. 1981. "Draft Evasion in the North during the Civil War, 1863-1865," Journal of American History 67: 816-34.

C. Lee. 1997. "Socioeconomic Background, Disease, and Mortality among Union Army Recruits: Implications for Economic and Demographic History," Explorations in Economic History 34, 27-55.

. 1999. "Selective Assignment of Military Positions in the Union Army: Implications for the Impact of the Civil War," Social Science History 23, 67-97.

. 2002. "Sectoral Shift and the Labor-Force Participation of Older Males in the United States, 1880-1940, Journal of Economic History 62, 512-523.

. 2003. "Prior Exposure to Disease, and Later Health and Mortality: Evidence from Civil War Medical Records," In D. Costa, ed., Health and Labor Force Participation over the Life Cycle. Chicago: University of Chicago Press.

Lund M., D. Foy, C. Sipprelle, and A. Strachan. 1984. "The Combat Exposure Scale: A Systematic Assessment of Trauma in the Vietnam War," Journal of Clinical Psychology 40, $1323-328$. 
McClellan, M. 1998. "Health Events, Health Insurance, and Labor Supply: Evidence from Health and Retirement Survey," In D. Wise, ed., Frontiers in the Economics of Aging. Chicago: University of Chicago Press, 301-346.

McDonough, P., G. Duncan, D. Williamson, and J. House. 1997. "Income Dynamics and Adult Mortality in the United States, 1972 through 1989," American Journal of Public Health 87, 1479-1583.

Meara, E. 2001. "Why is Health Related to Socioeconomic Status? The Case of Pregnancy and Low Birth Weight,” NBER Working Paper No. 8231.

Meer, J., D. Miller, and H. Rosen. 2003. "Exploring the Health-Wealth Nexus," NBER Working Paper No. 9554.

Murdock, E. C. 1964. “Was It A 'Poor Man’s Fight’?” Civil War History 10, 241-45.

Nefzger, M. Dean. 1970. "Follow-up Studies of World War II and Korean War Prisoners, I. Study Plan and Mortality Findings,” American Journal of Epidemiology 91, 123-138.

Pedersen, H. 1950. "A Cultural Evaluation of the Family Farm Concept," Land Economics $26,52-64$.

Pope, C. L. 1989. "Households on the American Frontier: The Distribution of Income and Wealth in Utah, 1850-1900," In D. W. Galenson, ed., Markets in History. Cambridge: Cambridge University Press.

Preston, S. H., and Haines, M. R. 1991. Fatal Years: Child Mortality in Late Nineteenth Century America. Princeton NJ: Princeton University Press.

Preston, S. H., Haines, M. R., and Pamuk, E. 1981, "Effects of Industrialization and Urbanization on Mortality in Developed Countries," In International Union for the Scientific Study of Population. International Population Conference, Manila, 1981: 
Solicited Papers, vol. 2. Liege: IUSSP, 233-54.

Smith, C. I. et al. 1987. "Evidence of Hepatitis Virus Infection among Australian Prisoners of War during World War II," Medial Journal of Austria 147, 229-230.

Smith, J. P. 1999. "Healthy Bodies and Thick Wallets: The Dual Relation between Health and Economic Status, Journal of Economic Perspectives 13, 145-166.

Soltow, L. 1975. Men and Wealth in the United States. New Haven: Yale University Press.

Spaulding R. C. 1977. "The Pueblo Incident: Medical Problems Reported During Captivity and Physical Findings at the Time of the Crew's Release," Military Medicine, 681-684.

Steckel, R. 1988. "The Health and Mortality of Women and Children, 1850-1860," Journal of Economic History 48, 333-45.

Strauss, J., and D. Thomas. 1992. "Health, Nutrition, and Economic Development," Journal of Economic Literature 36, 766-817.

Sutker, P., D. Winstead, Z. Galina and A. Allan. 1991. "Cognitive Deficits and Psychopathology among Former Prisoners of War and Combat Veterans of the Korean Conflicts," American Journal of Psychiatry 148, 67-72.

Thernstrom, S. 1964. Poverty and Progress. Cambridge: Harvard University Press. . 1973. The other Bostonians. Cambridge, MA: Harvard University Press.

Ursano, Robert J. 1990. “The Prisoner of War,” Military Medicine 155, 176-180.

U.S. Bureau of the Census. 1866. Eighth Census: 1860 Statistics of the United States, Including Mortality. Washington, DC: Government Printing Office. 
. 1950. 1950 Census of Population Alphabetical Index of Occupations and Industries. Washington, DC: Government Printing Office. . 1975. Historical Statistics of the United States: Colonial Times to 1970. Washington, DC: Government Printing Office.

U.S. Surgeon General's Office. 1870. Medical and Surgical History of the War of the Rebellion. Washington, DC: Government Printing Office.

Vinovskis, M. A. 1990. "Have Social Historians Lost the Civil War? Some Preliminary Demographic Speculations," In Vinovskis, M. A. ed., Toward A Social History of the American Civil War. New York: Cambridge Univ. Press, 1-30.

Wimmer, L. 2003 (forthcoming), "Reflections on the 'Early Indicator's Project': A Partial History," In D. Costa, ed., Health and Labor Force Participation over the Life Cycle. Chicago: University of Chicago Press. 
Table 1

Some Characteristics of the Entire and Selected Samples

\begin{tabular}{|c|c|c|c|c|}
\hline Variables & $\begin{array}{c}\text { Entire Union } \\
\text { Army sample } \\
\mathrm{N}=35,784\end{array}$ & $\begin{array}{l}\text { Sample searched } \\
\text { in the } 1870 \text { census } \\
\mathrm{N}=4397\end{array}$ & $\begin{array}{c}\text { Sample linked to } \\
\text { the } 1870 \text { census } \\
\quad N=1863\end{array}$ & $\begin{array}{c}\text { Sample linked to } \\
\text { the } 1860 \text { and } 1870 \\
\text { census } \\
N=1097\end{array}$ \\
\hline \multicolumn{5}{|l|}{ Personal Characteristics } \\
\hline Age in 1860 & 23.1 & 23.3 & 23.6 & 24.4 \\
\hline Height (inch) & 67.5 & 68.0 & 68.2 & 68.4 \\
\hline U.S. born $(\%)$ & 69.4 & 71.9 & 83.0 & 86.8 \\
\hline \multicolumn{5}{|l|}{ Occupational Composition (\%) } \\
\hline Farmers & 48.8 & 59.1 & 67.7 & 69.8 \\
\hline Professionals and Managers & 7.6 & 8.2 & 7.4 & 7.4 \\
\hline Craftsmen \& Semiskilled & 25.1 & 20.4 & 17.8 & 16.6 \\
\hline Unskilled \& No jobs & 17.2 & 11.3 & 6.8 & 6.3 \\
\hline \multicolumn{5}{|l|}{ Region of Enlistment (\%) } \\
\hline New England & 7.4 & 7.8 & 7.6 & 8.6 \\
\hline Mid Atlantic & 34.5 & 8.8 & 7.8 & 7.9 \\
\hline East North Central & 42.0 & 20.2 & 12.8 & 12.6 \\
\hline West North Central & 8.9 & 54.6 & 59.8 & 57.2 \\
\hline South & 5.3 & 8.6 & 12.1 & 13.7 \\
\hline \multicolumn{5}{|l|}{ Year of Enlistment (\%) } \\
\hline 1861 & 25.5 & 22.8 & 24.4 & 23.6 \\
\hline 1862 & 33.8 & 35.2 & 35.4 & 34.4 \\
\hline 1863 & 6.8 & 6.4 & 6.3 & 6.2 \\
\hline 1864 & 22.7 & 30.4 & 27.9 & 29.1 \\
\hline 1865 & 10.8 & 5.2 & 6.1 & 6.7 \\
\hline \multicolumn{5}{|l|}{ Wartime Medical Experience } \\
\hline Wounded $(\%)$ & 27.1 & 23.3 & 25.5 & 24.3 \\
\hline Illness $(\%)$ & 64.4 & 64.3 & 72.1 & 71.8 \\
\hline Mean wound cases & 0.57 & 0.47 & 0.50 & 0.48 \\
\hline Mean Illness cases & 2.19 & 2.38 & 2.73 & 2.78 \\
\hline \multicolumn{5}{|l|}{ Linkage Information (\%) } \\
\hline Death dates known & 70.0 & 72.3 & 89.8 & 90.7 \\
\hline Linked to pension data & 68.5 & 77.6 & 93.9 & 94.9 \\
\hline
\end{tabular}


Table 2

Wartime Medical Experiences of the Veterans in the Sample Linked to the 1870 Census

\begin{tabular}{|l|c|c|c|c|}
\hline \multirow{2}{*}{ Medical Experiences } & \multicolumn{2}{|c|}{ Number of cases } & \multicolumn{2}{c|}{ Proportion having any case } \\
\cline { 2 - 5 } & Mean & SD & Mean & SD \\
\hline Wounds in general & 0.4855 & 1.0968 & 0.2437 & 0.4295 \\
Wounds, arm/hand & & & & \\
Wounds, leg/foot & 0.0947 & 0.4325 & 0.0656 & 0.2477 \\
Wounds, body & 0.1546 & 0.5935 & 0.0918 & 0.2889 \\
Wounds, head/face & 0.0469 & 0.2482 & 0.0394 & 0.1945 \\
Wounds, unclassified & 0.0337 & 0.2918 & 0.0178 & 0.1323 \\
Illnesses in general & 0.0600 & 0.2673 & 0.0534 & 0.2250 \\
& 2.7778 & 3.2414 & 0.7179 & 0.4502 \\
Typhoid & & & & \\
Smallpox & 0.0431 & 0.2209 & 0.0394 & 0.1945 \\
Measles & 0.0225 & 0.1824 & 0.0169 & 0.1288 \\
Diarrhea & 0.0750 & 0.3411 & 0.0572 & 0.2323 \\
Respiratory infections & 0.5904 & 1.1988 & 0.2999 & 0.4584 \\
Malaria & 0.0778 & 0.2978 & 0.0703 & 0.2558 \\
Tuberculosis & 0.3365 & 0.9281 & 0.1893 & 0.3919 \\
Rheumatism & 0.0131 & 0.1138 & 0.0131 & 0.1138 \\
Syphilis & 0.1350 & 0.4423 & 0.1040 & 0.3054 \\
Hernia & 0.0084 & 0.1101 & 0.0066 & 0.0808 \\
\end{tabular}

Note: Calculated for 1067 men who had complete information on medical experiences while in service. 
Table 3

Logistic and OLS Regressions: Socioeconomic Backgrounds and Wartime Experiences

\begin{tabular}{|c|c|c|c|c|c|c|c|c|}
\hline \multirow[t]{2}{*}{ Variable } & \multicolumn{2}{|c|}{$\begin{array}{c}\text { (1) } \\
\text { Dying from disease } \\
\text { (Logistic Regression) }\end{array}$} & \multicolumn{2}{|c|}{$\begin{array}{c}(2) \\
\text { Dying from injury } \\
\text { (Logistic Regression) }\end{array}$} & \multicolumn{2}{|c|}{$\begin{array}{c}\text { (3) } \\
\text { Contracting disease } \\
\text { (Logistic Regression) }\end{array}$} & \multicolumn{2}{|c|}{$\begin{array}{c}(4) \\
\text { Suffering injury } \\
\text { (Logistic Regression) }\end{array}$} \\
\hline & Odd ratio & P-value & Odd ratio & P-value & Odd ratio & P-value & Odd ratio & P-value \\
\hline \multicolumn{9}{|l|}{ Intercept } \\
\hline Age & 0.974 & 0.2200 & 1.068 & 0.1323 & 0.905 & 0.0001 & 0.947 & 0.0018 \\
\hline Age squared & 1.006 & 0.0702 & 0.987 & 0.0826 & 1.017 & 0.0001 & 1.009 & 0.0021 \\
\hline Height & 0.875 & 0.5614 & 0.611 & 0.0414 & 1.301 & 0.1564 & 1.000 & 0.9989 \\
\hline Height squared & 1.010 & 0.5489 & 1.035 & 0.0541 & 0.981 & 0.1571 & 1.001 & 0.9618 \\
\hline Farmer & NI & NI & NI & NI & NI & NI & NI & NI \\
\hline Rural nonfarmer & 0.574 & 0.0001 & 0.908 & 0.3608 & 0.654 & 0.0001 & 0.785 & 0.0001 \\
\hline Urban & 0.404 & 0.0001 & 0.788 & 0.1996 & 0.379 & 0.0001 & 1.111 & 0.2234 \\
\hline U.S. born & 0.749 & 0.0010 & 0.669 & 0.0006 & 1.205 & 0.0022 & 0.888 & 0.0424 \\
\hline Log adjusted wealth & 1.004 & 0.8027 & 0.995 & 0.8120 & 0.969 & 0.0011 & 0.994 & 0.4914 \\
\hline Enlisted in 1861 & NI & NI & NI & NI & NI & NI & NI & NI \\
\hline Enlisted in 1862 & 1.104 & 0.2265 & 1.023 & 0.8329 & 0.870 & 0.0243 & 1.215 & 0.0002 \\
\hline Enlisted in 1863 & 1.271 & 0.1144 & 0.772 & 0.2691 & 0.962 & 0.7533 & 1.365 & 0.0033 \\
\hline Enlisted in 1864 & 0.483 & 0.0001 & 0.392 & 0.0001 & 0.340 & 0.0001 & 2.817 & 0.0001 \\
\hline Enlisted in 1865 & 0.411 & 0.0001 & 0.018 & 0.0001 & 0.401 & 0.0001 & 2.602 & 0.0001 \\
\hline \multirow[t]{2}{*}{ Variable } & \multicolumn{2}{|c|}{$\begin{array}{c}\text { (5) } \\
\text { Infantry duty } \\
\text { (Logistic Regression) }\end{array}$} & \multicolumn{2}{|c|}{$\begin{array}{c}\text { (6) } \\
\text { Rank of Private } \\
\text { (Logistic Regression) }\end{array}$} & \multicolumn{2}{|c|}{$\begin{array}{l}\text { (7) } \\
\text { Company mortality } \\
\text { from illness (OLS) }\end{array}$} & \multicolumn{2}{|c|}{$\begin{array}{c}(8) \\
\text { Company mortality } \\
\text { from injury (OLS) } \\
\end{array}$} \\
\hline & Odd ratio & P-value & Odd ratio & P-value & Parameter & P-value & Parameter & $\mathrm{P}$-value \\
\hline Intercept & & & & & 0.0160 & 0.9261 & 0.1202 & 0.0078 \\
\hline Age & 0.947 & 0.0018 & 0.842 & 0.0001 & -0.0005 & 0.3203 & 0.0010 & 0.0003 \\
\hline Age squared & 1.009 & 0.0021 & 1.025 & 0.0001 & 0.0001 & 0.1614 & -0.0002 & 0.0001 \\
\hline Height & 1.000 & 0.9989 & 2.307 & 0.0023 & 0.0029 & 0.5746 & -0.0018 & 0.5424 \\
\hline Height squared & 1.001 & 0.9618 & 0.935 & 0.0007 & -0.0002 & 0.6773 & 0.0001 & 0.6816 \\
\hline Farmer & NI & NI & NI & NI & NI & NI & NI & NI \\
\hline Rural nonfarmer & 0.785 & 0.0001 & 0.524 & 0.0001 & -0.0252 & 0.0001 & 0.0029 & 0.0001 \\
\hline Urban & 1.111 & 0.2234 & 0.608 & 0.0002 & -0.0664 & 0.0001 & -0.0005 & 0.6930 \\
\hline U.S. born & 0.888 & 0.0424 & 0.689 & 0.0001 & -0.0161 & 0.0001 & -0.0104 & 0.0001 \\
\hline Log adjusted wealth & 0.994 & 0.4912 & 0.896 & 0.0001 & -0.0001 & 0.6846 & 0.0005 & 0.0009 \\
\hline Enlisted in 1861 & NI & NI & NI & NI & NI & NI & NI & NI \\
\hline Enlisted in 1862 & 1.215 & 0.0002 & 0.972 & 0.7141 & 0.0161 & 0.0001 & 0.0078 & 0.0001 \\
\hline Enlisted in 1863 & 1.365 & 0.0033 & 4.107 & 0.0001 & 0.0180 & 0.0001 & -0.0038 & 0.0276 \\
\hline Enlisted in 1864 & 2.817 & 0.0001 & 2.789 & 0.0001 & -0.0380 & 0.0001 & -0.0143 & 0.0001 \\
\hline Enlisted in 1865 & 2.602 & 0.0001 & 4.093 & 0.0001 & -0.0482 & 0.0001 & -0.0326 & 0.0001 \\
\hline
\end{tabular}

Notes. Number of observations for all regressions is 10,124. Dependent variable is one if the recruit died from disease for (1), died from injury for (2), contracted disease for (3), was injured for (4), was assigned an infantry duty for (5), and was given the lowest rank for (6), and is zero, otherwise. Dependent variable is the company mortality from illness for (7), and the company mortality from injury for (8). 
Table 4

Wartime Experiences by the Range of Instrumental Variables

\begin{tabular}{|c|c|c|c|c|c|}
\hline $\begin{array}{c}\text { Instrumental } \\
\text { variable }\end{array}$ & Range & $\begin{array}{c}\text { Proportion of } \\
\text { recruits in the } \\
\text { category }\end{array}$ & $\begin{array}{c}\text { Average length } \\
\text { of service } \\
\text { (year) }\end{array}$ & $\begin{array}{c}\text { Proportion of } \\
\text { recruits wounded } \\
\text { in service }\end{array}$ & $\begin{array}{c}\text { Proportion of } \\
\text { recruits having } \\
\text { any illness }\end{array}$ \\
\hline & Nobody killed & 0.2231 & 1.1793 & 0.0882 & 0.4580 \\
Company & over 0\% to 2\% & 0.1987 & 2.0206 & 0.1605 & 0.7830 \\
over 2\% to 4\% & 0.1022 & 1.5774 & 0.2294 & 0.6881 \\
wortality from & over 4\% to 6\% & 0.1912 & 2.4247 & 0.3824 & 0.8284 \\
& over 6\% to 8\% & 0.0956 & 2.0175 & 0.3039 & 0.8333 \\
& over 8\% to 10\% & 0.0806 & 2.0255 & 0.2558 & 0.8023 \\
over 10\% & 1861 & 0.1087 & 2.3837 & 0.4224 & 0.8017 \\
Year of & 1862 & 0.3449 & 2.9482 & 0.3889 & 0.8056 \\
& 1863 & 0.0619 & 2.4693 & 0.2745 & 0.8370 \\
& 1864 & 0.2915 & 1.7392 & 0.2879 & 0.8485 \\
& 1865 & 0.0656 & 0.7274 & 0.1286 & 0.5820 \\
enlistment & Mar. - May & 0.1051 & 0.4394 & 0.0286 & 0.2571 \\
\hline enlistment & Jun. - Aug. & 0.4484 & 2.5083 & 0.1071 & 0.5268 \\
& Sep. - Nov. & 0.2955 & 1.6743 & 0.3117 & 0.8494 \\
& Dec. - Feb. & 0.1510 & 1.1931 & 0.2317 & 0.6667 \\
\hline
\end{tabular}


Table 5

OLS Regressions: Correlates of Wealth Accumulation between 1860 and 1870

\begin{tabular}{|c|c|c|c|c|c|c|c|}
\hline \multirow[t]{2}{*}{ Variable } & \multirow[t]{2}{*}{ Mean } & \multicolumn{2}{|c|}{$\begin{array}{c}(1) \\
\ln (1870 \text { total wealth }) \\
\end{array}$} & \multicolumn{2}{|c|}{$\begin{array}{c}(2) \\
\ln (1870 \text { personal wealth })\end{array}$} & \multicolumn{2}{|c|}{$\begin{array}{c}(3) \\
\ln (1870 \text { real wealth }) \\
\end{array}$} \\
\hline & & Estimate & P-value & Estimate & P-value & Estimate & P-value \\
\hline Intercept & & 2.2967 & 0.0230 & 1.6250 & 0.1084 & 1.7614 & 0.0912 \\
\hline Company Mortality & & & & & & & \\
\hline Co wound mortality 1 & 0.212 & NI & NI & NI & NI & NI & NI \\
\hline Co wound mortality 2 & 0.275 & -0.3775 & 0.0916 & -0.4764 & 0.0334 & 0.0108 & 0.9628 \\
\hline Co wound mortality 3 & 0.182 & -0.5062 & 0.0488 & -0.6671 & 0.0095 & -0.0708 & 0.7889 \\
\hline Co wound mortality 4 & 0.331 & -0.6151 & 0.0098 & -0.6240 & 0.0087 & -0.5181 & 0.0354 \\
\hline Wounds & 0.241 & -0.3697 & 0.0334 & -0.3368 & 0.0527 & -0.1149 & 0.5216 \\
\hline Illnesses & 0.721 & 0.0817 & 0.6429 & 0.1889 & 0.2843 & 0.1173 & 0.5192 \\
\hline $\ln (1860$ total wealth) & 5.667 & 0.1290 & 0.0016 & & & & \\
\hline $\ln (1860$ personal wealth) & 5.291 & & & 0.1307 & 0.0023 & & \\
\hline $\ln (1860$ real wealth $)$ & 1.624 & & & & & 0.1606 & 0.0001 \\
\hline $\ln (1860$ other family wealth) & 3.604 & 0.0214 & 0.4035 & 0.0160 & 0.5422 & 0.0274 & 0.2662 \\
\hline 1860 Age & 23.741 & 0.2748 & 0.0003 & 0.2582 & 0.0007 & 0.2533 & 0.0013 \\
\hline $1860 \mathrm{Age}^{2} \mathrm{H} 10^{-2}$ & 62.184 & -0.0447 & 0.0018 & -0.0433 & 0.0025 & -0.0381 & 0.0101 \\
\hline U.S. Born & 0.868 & 0.2380 & 0.2902 & 0.4263 & 0.0577 & -0.0597 & 0.7947 \\
\hline Illiterate & 0.085 & -0.6078 & 0.0206 & -0.8671 & 0.0010 & 0.1093 & 0.6864 \\
\hline \multicolumn{8}{|l|}{ Height } \\
\hline Height $5^{\text {th }}$ quintile & 0.118 & 0.3609 & 0.1732 & 0.2022 & 0.4452 & -0.1966 & 0.4723 \\
\hline Height $4^{\text {th }}$ quintile & 0.154 & -0.0351 & 0.8854 & -0.2423 & 0.3196 & -0.2995 & 0.2330 \\
\hline Height $3^{\text {rd }}$ quintile & 0.201 & NI & NI & NI & NI & NI & NI \\
\hline Height $2^{\text {nd }}$ quintile & 0.267 & 0.2080 & 0.3288 & 0.0618 & 0.7718 & 0.0668 & 0.7612 \\
\hline Height $1^{\text {st }}$ quintile & 0.260 & 0.5337 & 0.0127 & 0.2975 & 0.1645 & 0.1523 & 0.4897 \\
\hline \multicolumn{8}{|l|}{ Region of enlistment } \\
\hline New England & 0.123 & 0.4718 & 0.1992 & 0.2496 & 0.4973 & 1.1121 & 0.0035 \\
\hline Mid Atlantic & 0.085 & -0.4796 & 0.1769 & -0.2546 & 0.4744 & -0.1738 & 0.6354 \\
\hline North East Central & 0.082 & NI & NI & $\mathrm{NI}$ & NI & NI & NI \\
\hline North West Central & 0.569 & 0.5115 & 0.0511 & 0.3844 & 0.1432 & 0.7322 & 0.0069 \\
\hline South & 0.142 & -0.2474 & 0.4783 & -0.4397 & 0.2079 & 0.4820 & 0.1809 \\
\hline \multicolumn{8}{|l|}{ Size of location, $1860 \& 1870$} \\
\hline Rural-Rural & 0.711 & NI & NI & NI & NI & NI & NI \\
\hline Rural-Urban & 0.131 & -0.2940 & 0.1933 & -0.3728 & 0.0992 & -0.3933 & 0.0916 \\
\hline Urban-Rural & 0.040 & 0.0357 & 0.9278 & 0.0851 & 0.8289 & -0.2472 & 0.5424 \\
\hline Urban-Urban & 0.118 & -0.0229 & 0.4374 & -0.4327 & 0.1320 & -0.6426 & 0.0304 \\
\hline \multicolumn{8}{|l|}{ Children } \\
\hline Younger than 10 in 1860 & 0.817 & -0.1549 & 0.1274 & -0.1642 & 0.1074 & -0.1274 & 0.2213 \\
\hline Age 10 and older in 1860 & 0.192 & 0.0635 & 0.6605 & 0.0253 & 0.8614 & 0.0134 & 0.9284 \\
\hline Younger than 10 in 1870 & 1.520 & 0.1510 & 0.0090 & 0.0847 & 0.1424 & 0.1727 & 0.0038 \\
\hline Age 10 and older in 1870 & 0.755 & 0.1570 & 0.1258 & 0.2070 & 0.0442 & 0.0149 & 0.8878 \\
\hline \multicolumn{8}{|l|}{ Geographic mobility } \\
\hline Same county & 0.618 & NI & NI & NI & NI & $\mathrm{NI}$ & NI \\
\hline Moved to different county & 0.197 & -0.3528 & 0.0669 & -0.3213 & 0.0952 & -0.2889 & 0.1464 \\
\hline Moved to different state & 0.185 & -0.5762 & 0.0144 & -0.3675 & 0.1186 & -0.7121 & 0.0034 \\
\hline \multicolumn{8}{|l|}{ Occupation, $1860 \& 1870$} \\
\hline Farmer, Farmer & 0.343 & NI & NI & NI & NI & NI & NI \\
\hline Farmer, Skilled & 0.029 & -0.2397 & 0.5878 & -1.4835 & 0.0008 & 0.4574 & 0.3163 \\
\hline Farmer, Unskilled & 0.014 & -0.1228 & 0.8401 & 0.0020 & 0.9974 & 0.1286 & 0.8378 \\
\hline Skilled, Farmer & 0.029 & 0.4120 & 0.3485 & 0.3889 & 0.3764 & 0.9332 & 0.0399 \\
\hline Skilled, Skilled & 0.106 & -1.5609 & 0.0001 & -1.4534 & 0.0001 & -1.8713 & 0.0001 \\
\hline Skilled, Unskilled & 0.031 & -2.1016 & 0.0001 & -1.7801 & 0.0001 & -3.7413 & 0.0001 \\
\hline Unskilled, Farmer & 0.019 & -0.0989 & 0.8596 & -1.1380 & 0.0423 & 0.6278 & 0.2781 \\
\hline Unskilled, Skilled & 0.049 & -2.4873 & 0.0001 & -1.8228 & 0.0001 & -4.3565 & 0.0001 \\
\hline Unskilled, Unskilled & 0.263 & -2.2535 & 0.0001 & -1.2088 & 0.0001 & -5.5111 & 0.0001 \\
\hline \multirow{2}{*}{\multicolumn{2}{|c|}{$\begin{array}{l}\text { Adjusted } \mathrm{R}^{2} \\
\mathrm{~F}\end{array}$}} & \multicolumn{2}{|l|}{0.3084} & \multicolumn{2}{|l|}{0.1946} & \multicolumn{2}{|l|}{0.6110} \\
\hline & & 13.10 & 0.0001 & 7.56 & 0.0001 & 43.62 & 0.0001 \\
\hline
\end{tabular}

Note: The sample is limited to 978 veterans who were linked to the 1860 and 1870 censuses and for whom information on all independent variables is given. NI stands for "Not Included." 
Table 6

OLS Regressions: Effects of Particular Types of Wounds and Illnesses on Wealth Accumulation

\begin{tabular}{|c|c|c|c|c|c|c|c|}
\hline \multirow[t]{2}{*}{ Variable } & \multirow[t]{2}{*}{ Mean } & \multicolumn{2}{|c|}{$\begin{array}{c}(1) \\
\ln (1870 \text { total wealth })\end{array}$} & \multicolumn{2}{|c|}{$\begin{array}{c}(2) \\
\ln (1870 \text { personal wealth })\end{array}$} & \multicolumn{2}{|c|}{$\begin{array}{c}(3) \\
\ln (1870 \text { real wealth })\end{array}$} \\
\hline & & Estimate & P-value & Estimate & P-value & Estimate & P-value \\
\hline \multicolumn{8}{|l|}{ Company Mortality } \\
\hline Co wound mortality 1 & 0.212 & NI & NI & NI & NI & NI & NI \\
\hline Co wound mortality 2 & 0.275 & -0.3093 & 0.1621 & -0.4065 & 0.0661 & 0.0816 & 0.7214 \\
\hline Co wound mortality 3 & 0.182 & -0.4098 & 0.1092 & -0.5806 & 0.0231 & 0.0358 & 0.8918 \\
\hline Co wound mortality 4 & 0.331 & -0.5054 & 0.0320 & -0.5199 & 0.0270 & -0.3773 & 0.1225 \\
\hline \multicolumn{8}{|l|}{ Wounds by location } \\
\hline Arm/Hand/Finger & 0.063 & -0.3581 & 0.2393 & -0.1624 & 0.5931 & -0.4547 & 0.1487 \\
\hline Leg/Foot/Toe & 0.094 & -0.5629 & 0.0270 & -0.4373 & 0.0854 & -0.1418 & 0.5897 \\
\hline Body & 0.042 & -0.1711 & 0.6393 & -0.1509 & 0.6790 & 0.0270 & 0.9430 \\
\hline Head/Face & 0.017 & 0.1571 & 0.7770 & 0.1747 & 0.7526 & 0.5266 & 0.3590 \\
\hline Unclassified & 0.054 & -0.4348 & 0.1876 & -0.3702 & 0.2615 & -0.2481 & 0.4674 \\
\hline \multicolumn{8}{|l|}{ Illnesses by type } \\
\hline Typhoid & 0.043 & 0.2506 & 0.4856 & 0.2695 & 0.4528 & 0.1335 & 0.7190 \\
\hline Smallpox & 0.016 & 0.2718 & 0.6371 & 0.3675 & 0.5232 & -0.0053 & 0.9929 \\
\hline Measles & 0.057 & -0.2576 & 0.4129 & -0.0390 & 0.9014 & 0.0130 & 0.9682 \\
\hline Diarrhea & 0.301 & -0.3089 & 0.0639 & -0.4621 & 0.0056 & -0.0691 & 0.6886 \\
\hline Respiratory infections & 0.070 & -0.2313 & 0.4206 & -0.1277 & 0.6564 & 0.4365 & 0.1424 \\
\hline Malaria & 0.194 & 0.2603 & 0.1769 & 0.4411 & 0.0221 & -0.1917 & 0.3358 \\
\hline Tuberculosis & 0.013 & 0.1175 & 0.8527 & 0.3269 & 0.6053 & 0.5120 & 0.4346 \\
\hline Rheumatism & 0.103 & -0.0661 & 0.7861 & -0.0414 & 0.8651 & -0.1734 & 0.4921 \\
\hline Syphilis & 0.006 & -0.2951 & 0.7495 & -1.0401 & 0.2600 & -0.0031 & 0.9975 \\
\hline Hernia & 0.011 & -0.4170 & 0.5431 & -0.4159 & 0.5439 & 0.6537 & 0.3573 \\
\hline \multirow{2}{*}{\multicolumn{2}{|c|}{ Adjusted $\mathrm{R}^{2}$}} & \multicolumn{2}{|l|}{0.3088} & \multicolumn{2}{|l|}{0.1973} & \multicolumn{2}{|l|}{0.6092} \\
\hline & & 9.91 & 0.0001 & 5.90 & 0.0001 & 32.08 & 0.0001 \\
\hline
\end{tabular}

Note: The same sample and specification as those used in the regressions reported in Table 5 are used, except the variables on wounds and illnesses. 
Table 7

Effects of Wounds and Diseases on Wealth Accumulation: Results of Instrumental Variable Estimations

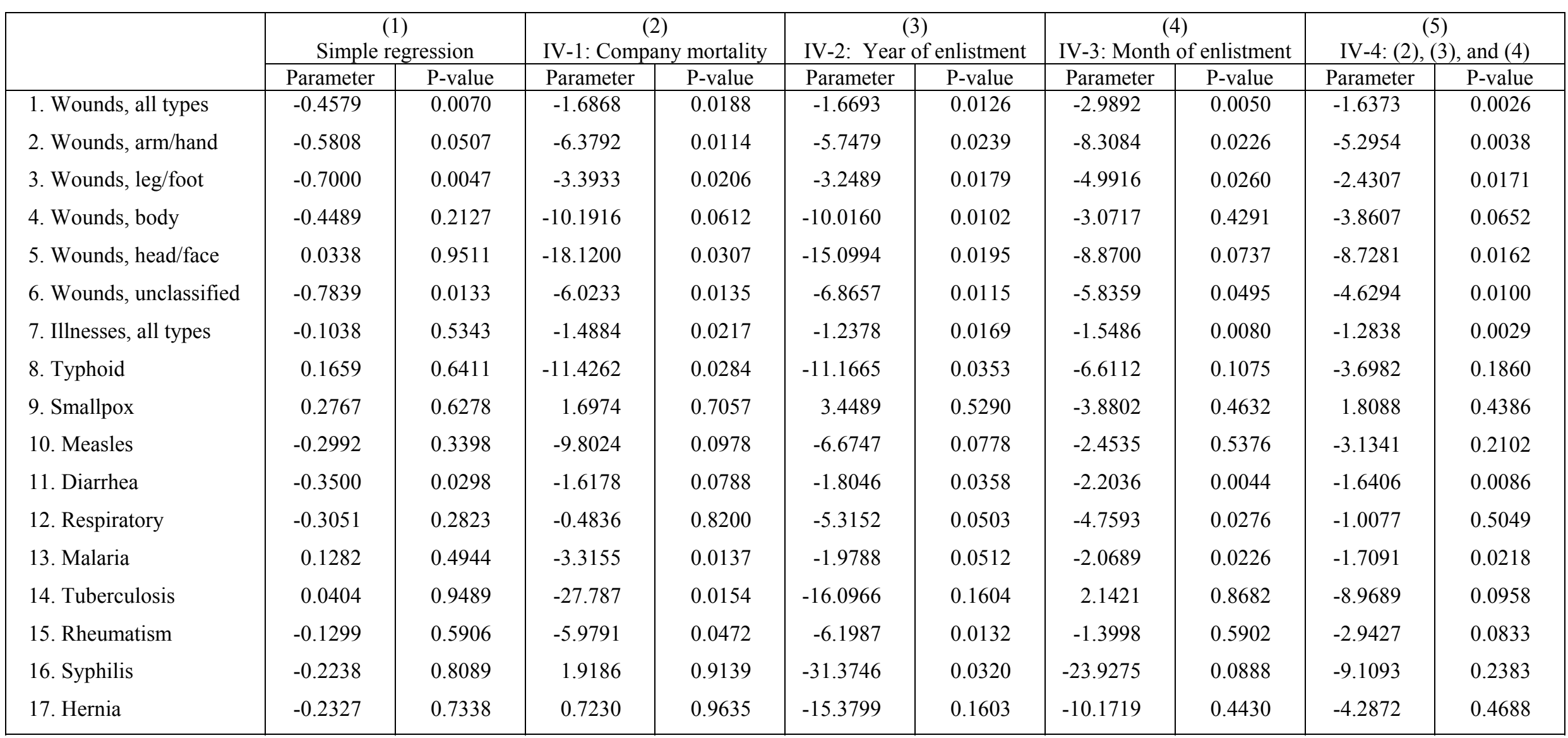

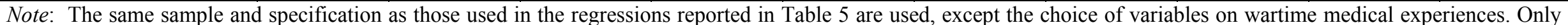
the results for the variables on wounds and illnesses obtained from 85 different regressions are presented here. 
Table 8

OLS Regressions: Effects of Wartime Medical Experiences on Wealth Accumulation by Occupation

\begin{tabular}{|c|c|c|c|c|c|c|}
\hline \multirow{2}{*}{ Variable } & \multicolumn{2}{|c|}{$\begin{array}{c}(1) \\
\text { Farmer }(\mathrm{N}=393)\end{array}$} & \multicolumn{2}{|c|}{$\begin{array}{c}(2) \\
\text { White-collar/Skilled }(\mathrm{N}=224)\end{array}$} & \multicolumn{2}{|c|}{$\begin{array}{c}(3) \\
\text { Unskilled }(\mathrm{N}=352) \\
\end{array}$} \\
\hline & Estimate & P-value & Estimate & P-value & Estimate & P-value \\
\hline $\begin{array}{l}\text { Company Mortality } \\
\text { Co wound mortality } 2 \\
\text { Co wound mortality } 3 \\
\text { Co wound mortality } 4 \\
\text { Wounds } \\
\text { Illnesses }\end{array}$ & $\begin{array}{r}-0.1146 \\
-0.0279 \\
-0.1964 \\
-0.1807 \\
0.2043 \\
\end{array}$ & $\begin{array}{l}0.3545 \\
0.8332 \\
0.1245 \\
0.0464 \\
0.0311 \\
\end{array}$ & $\begin{array}{r}-0.1588 \\
-0.8692 \\
-0.6146 \\
0.1461 \\
-0.3394 \\
\end{array}$ & $\begin{array}{l}0.7769 \\
0.2296 \\
0.2762 \\
0.7578 \\
0.4353 \\
\end{array}$ & $\begin{array}{r}-1.1122 \\
-1.2433 \\
-0.8674 \\
-1.0123 \\
0.0305 \\
\end{array}$ & $\begin{array}{l}0.0165 \\
0.0237 \\
0.0942 \\
0.0050 \\
0.9348 \\
\end{array}$ \\
\hline $\begin{array}{l}\text { Company Mortality } \\
\text { Co wound mortality } 2 \\
\text { Co wound mortality } 3 \\
\text { Co wound mortality } 4 \\
\text { Wounds by location } \\
\text { Arm/Hand/Finger } \\
\text { Leg/Foot/Toe } \\
\text { Body } \\
\text { Head/Face } \\
\text { Unclassified } \\
\text { Illnesses by type } \\
\text { Typhoid } \\
\text { Smallpox } \\
\text { Measles } \\
\text { Diarrhea } \\
\text { Respiratory infections } \\
\text { Malaria } \\
\text { Tuberculosis } \\
\text { Rheumatism } \\
\text { Syphilis } \\
\text { Hernia }\end{array}$ & $\begin{array}{r}-0.1249 \\
-0.0429 \\
-0.1906 \\
\\
-0.0092 \\
0.0438 \\
-0.2333 \\
0.0558 \\
-0.4289 \\
\\
0.1168 \\
0.3735 \\
0.0636 \\
0.0615 \\
-0.0830 \\
0.0170 \\
0.2924 \\
-0.2857 \\
-0.6439 \\
0.8583 \\
\end{array}$ & $\begin{array}{l}0.9588 \\
0.7817 \\
0.2579 \\
0.8344 \\
0.0305 \\
\\
0.5608 \\
0.2910 \\
0.7370 \\
0.5117 \\
0.6104 \\
0.8823 \\
0.4296 \\
0.0465 \\
0.2706 \\
0.0710 \\
\end{array}$ & $\begin{array}{r}-0.0258 \\
-0.5758 \\
-0.3501 \\
\\
-1.1532 \\
0.7124 \\
0.5922 \\
3.3715 \\
-0.9684 \\
\\
-1.0834 \\
-0.7358 \\
-1.0439 \\
-0.6504 \\
0.8191 \\
-0.1089 \\
\mathrm{NI} \\
0.0088 \\
\mathrm{NI} \\
-2.2207 \\
\end{array}$ & $\begin{array}{r}0.1108 \\
0.3317 \\
0.5440 \\
0.1280 \\
0.3012 \\
\\
0.2860 \\
0.7996 \\
0.3306 \\
0.1814 \\
0.3784 \\
0.8425 \\
\mathrm{NI} \\
0.9901 \\
\mathrm{NI} \\
0.1946 \\
\end{array}$ & $\begin{array}{r}-1.0060 \\
-1.0354 \\
-0.7663 \\
\\
0.1619 \\
-1.3772 \\
-0.6351 \\
-0.5642 \\
-1.0856 \\
\\
0.8882 \\
-0.0127 \\
-0.4162 \\
-0.4744 \\
-0.7741 \\
0.6581 \\
0.2028 \\
-0.1699 \\
-0.9213 \\
-0.3117 \\
\end{array}$ & $\begin{array}{l}0.8250 \\
0.0059 \\
0.4475 \\
0.6611 \\
0.1370 \\
\\
0.2515 \\
0.9894 \\
0.4645 \\
0.1804 \\
0.1663 \\
0.0949 \\
0.8403 \\
0.7350 \\
0.5685 \\
0.8087 \\
\end{array}$ \\
\hline $\begin{array}{l}\text { IV estimations } \\
\text { Wounds } \\
\text { Arm/hand } \\
\text { Leg/foot } \\
\text { Body } \\
\text { Head/face } \\
\text { Unclassified } \\
\text { Illnesses } \\
\text { Typhoid } \\
\text { Smallpox } \\
\text { Measles } \\
\text { Diarrhea } \\
\text { Respiratory } \\
\text { Malaria } \\
\text { Tuberculosis } \\
\text { Rheumatism } \\
\text { Syphilis } \\
\text { Hernia }\end{array}$ & $\begin{array}{r}-0.2083 \\
1.0220 \\
-0.6488 \\
-0.7325 \\
0.4189 \\
0.4069 \\
0.0016 \\
1.6068 \\
0.8571 \\
-0.7563 \\
0.0682 \\
0.5715 \\
0.3143 \\
0.6967 \\
-0.4187 \\
-0.3566 \\
2.2460\end{array}$ & $\begin{array}{l}0.4753 \\
0.1708 \\
0.2076 \\
0.3256 \\
0.6273 \\
0.6428 \\
0.9939 \\
0.1167 \\
0.2133 \\
0.2859 \\
0.7888 \\
0.3212 \\
0.4007 \\
0.7566 \\
0.5539 \\
0.8275 \\
0.0992\end{array}$ & $\begin{array}{r}-1.4776 \\
-6.3810 \\
-1.3125 \\
-3.9368 \\
-4.6623 \\
-4.0521 \\
-1.7487 \\
-4.2497 \\
-2.5999 \\
-6.1596 \\
-1.7103 \\
-1.4892 \\
-2.4425 \\
0.0728 \\
0.7127 \\
-24.0243 \\
-14.6420\end{array}$ & $\begin{array}{l}0.2170 \\
0.0213 \\
0.4295 \\
0.1143 \\
0.4454 \\
0.1449 \\
0.0714 \\
0.2224 \\
0.5038 \\
0.1027 \\
0.1909 \\
0.5845 \\
0.0903 \\
0.6676 \\
0.6676 \\
0.0523 \\
0.0017\end{array}$ & $\begin{array}{r}-2.5148 \\
-2.7980 \\
-2.8613 \\
-2.9288 \\
-9.8564 \\
-3.5935 \\
-1.9228 \\
-1.4266 \\
-1.5631 \\
-1.5910 \\
-2.4272 \\
-3.5650 \\
-1.4168 \\
4.3247 \\
-2.3980 \\
-0.3467 \\
5.1700\end{array}$ & $\begin{array}{l}0.0294 \\
0.2734 \\
0.1550 \\
0.3228 \\
0.0946 \\
0.2422 \\
0.0272 \\
0.6833 \\
0.5588 \\
0.6831 \\
0.0418 \\
0.1463 \\
0.3107 \\
0.3772 \\
0.4291 \\
0.9225 \\
0.3634\end{array}$ \\
\hline
\end{tabular}

Note: The same specification as those used in the regressions reported in Table 5 is used, except the choice of variables on wartime medical experiences and occupation. Only the results for the variables on wounds and illnesses obtained from 57 different regressions are presented here. Instrumental variables include fourth-order polynomials of the company mortality from wounds, dummy variables for the year of enlistment, and dummy variables for the month of enlistment. 


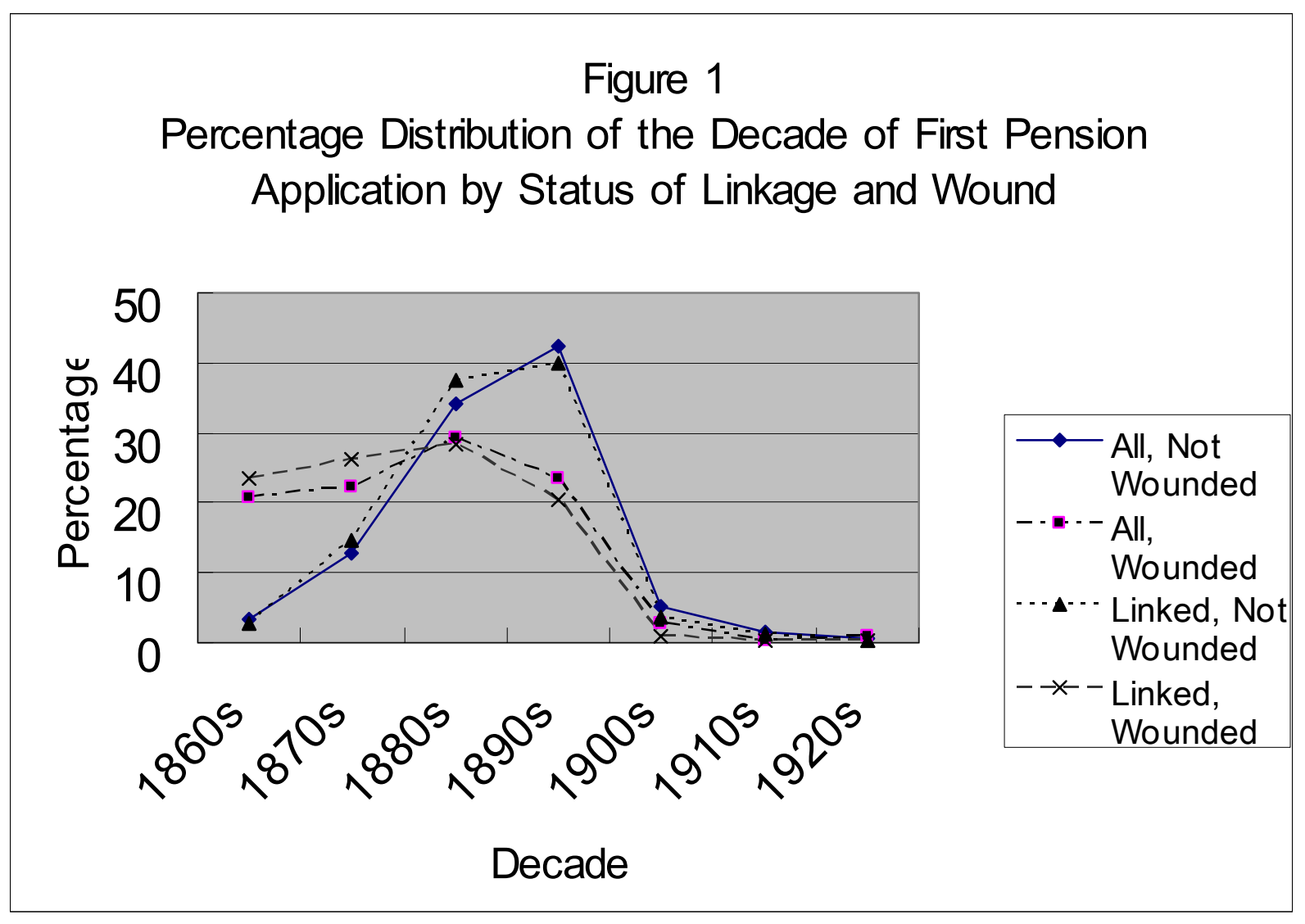

